Did FDI Increase Wage Inequality in Transition Economies?

\begin{tabular}{|r|l|}
\hline Journal: & International Journal of Social Economics \\
\hline Manuscript ID & IJSE-09-2017-0373.R1 \\
\hline Manuscript Type: & Research Paper \\
\hline Keywords: & Foreign direct investment, Wage inequality, Transition economies \\
\hline & \\
\hline
\end{tabular}

SCHOLARONE ${ }^{\text {m }}$

Manuscripts 


\title{
Did FDI Increase Wage Inequality in Transition Economies?
}

\begin{abstract}
Purpose of this paper -The last two decades have been characterised by a rise in income and wage inequality in a wide range of countries, including European transition countries. The rise in globalisation is one major factor explaining this increasing wage inequality. International trade and FDI have increased significantly since the beginning of transition and this paper focuses onexamines whether FDI plays an important role in explaining the pattern of wage inequality in selected transition countries.
\end{abstract}

Design/methodology/approach- A cross-country empirical investigation has been conducted using two alternative measures of wage inequality: the Gini coefficient and the Theil index. Several model specifications and estimation strategies have been employed to obtain consistent estimates and to check for the robustness of the results.

Findings- The results indicate that a rising share of inward FDI in GDP increased wage inequality in transition economies, though its overall effect was relatively small. Considering the long run, there is no clear evidence of a concave relationship between FDI and wage inequality, which may be a consequence of the relatively low high levels of FDI in manyest transition countries.

Practical implications -Inwards FDI has made a small contribution to increasing wage inequality in European transition economies. However, its overall beneficial effects on labour markets in these countries suggests that rather than restricting FDI governments should target increasing the supply of skilled labour.

What is original/value of paper- This new empirical evidence supports the hypothesis that an increased inward FDI stock as a share of GDP increases wage inequality in transition economies, however this relationship ismay be a complex one. Differences in average wages, wage differentials, employment shares of skilled workers and relative size of the foreignowned sector are all likely to be important for the behaviour of wage inequality.

\section{INTRODUCTION}

International trade and fForeign direct investment inflows have-increased significantly in European transition economies during the transition period. The resulting inflows of capital and technology affected the demand for labour and accordingly employment, productivity, wage levels and differentials and wage inequality. This paper focuses on a largely neglected area: the effect of inwards FDI on wage inequality in European transition economies (ETEs). Mitra and Yemtsov (2006) recorded the rise in inequality during transition but pointed out the diversity of outcomes across these countries. There is a significant body of research looking at the impact of FDI on wage inequality in other groups of countries. Hale and Xu's (20167) meta-analysis of that empirical literature concludes that in both developed and developing countries FDI increases the demand for skilled labour in host countries, increasing the overall demand for labour whilst raising skill premiums and average productivity and wages. They find that three-quarters of studies found a positive effect on wage inequality. Of particular interest for this study of ETEs, is their finding that the effects of FDI on host country labour markets were stronger in countries with scarce skilled labour and large technological gaps., which has motivated scholars to examine the impact of these factors on the labour market and more specifically on wage inequality. This paper examines whether inward FDI plays a major role in explaining the pattern of wage inequality in transition countries. Feenstra and Hanson (2001) argue that both trade in intermediate imputs and skilled biased, technological change 
have decreased the demand for low skilled labour and increased the-relative demand and wages of the higher skilled. Analysis presented in - Pprevious research suggestsed that the net effect of FDI on wage inequality will depend on how large are the relative skill wage differences between foreign-owned firms and domestic owned firms, the relative skillintensity of employment in foreign-owned firms compared to domestic ones and the relative size of the foreign-owned sector (Feenstra and Hanson, 20031; OECD, 2002; Estrin, 2017).

Notwithstanding the effects ofBefore the Global Financial Crisis, in their first two decades most ETEstransition economies had made significant progress in attracting FDI (UNCTAD, 2012). The decline in FDI flows during 2009 and 2010 in transition economies was halted in 2011, where FDI flows increased by $25 \%$ reaching $\$ 92$ billion driven mainly by cross border M\&A (UNCTAD, 2012). Very large inflows have been attracted by the larger economies, such as Russia and Poland (\$418,982 million and \$180,836 million between 1995 and 2012). Whereas, tiny inflows, less than $\$ 6$ million over the period 1995 to 2012 , characterize some low and middle-income transition economies, such as Armenia, Macedonia, Moldova, Kyrgyzstan and Tajikistan, attracted less than \$6m inflows during this period (Zulfiu-Alili, 2014). The increase in FDI into transition economies, especially after 2006, has been attributed to economic recovery and reform, a better investment climate, increased openness to FDI and the start of association (and accession) negotiations with the EU from 2005 (UNCTAD, 2010; 2013). FDI inflows to transition economies were not only directed at the most labour intensive and low value added activities but also, increasingly, at more innovative and technology intensive activities (UNCTAD, 2010). In South East European countries, FDI into manufacturing sector increased as a result of competitive production costs and open access to EU markets, whereas the CIS resource-based economies benefited from continued natural resource-seeking FDI.

Given that wages are the main source of income in transition countries, it is expected that changes in wage inequality drive changes in income inequality in ETEs. In assessing wage inequality most studies utilise the Gini coefficient as the measure of inequality. The size of these coefficients increased considerably after 1990s in transition countries (Milanovic, 1999; Milanovic, 2011). The evolution of the Gini coefficients for individual transition countries for which data are available show that Azerbaijan, Russia and Kyrgyzstan have experienced the highest levels of inequality during the period from 1997 to 2006, above 0.5 (Figure 1). There is some evidence of an inverse- $U$ pattern whereby inequality first increases and later falls as an economy develops. The lowest level of inequality among transition countries was found in the Czech Republic (0.26) and overall CEE countries now have, on average, similar levels of inequality to those found in EU15 countries (Roaf et al., 2014). Macedonia (0.28), Poland (0.30), Serbia (0.32) and Romania (0.35) have upward trends in wage inequality from 1993 to 2008.

$\underline{\text { Figure 1. Distribution of earnings in selected transition economies: Gini coefficient }}$ 
Wage inequality was generally higher in CIS countries than in CEE and SEE countries. These increases in inequality have been attributed to a range of factors, such as globalisation, skilled-biased technological change, differential access to schooling, labour reallocation, high unemployment and institutional changes (Franco and Gerussi, 2010; Rose, 2014; Aristei and Perugini, 2014; Satti et al., 2015; Tyrowicz et al., 2017). Whilst the diversity of experience amongst ETEs has been attributed to differences in initial conditions, country specifics and policy choices (Mitra and Yemtsov, 2006).

The remainder of this paper is organised as follows. In Section 2 a review of relevant theory and previous empirical research is presented. This discussion informs the specification of the model of wage inequality presented in Section 3. This section also explains the data used and examines the descriptive statistics of the variables of interest. The empirical approach taken to estimate the wage inequality model is explained in Section 4. The following section presents and interprets the results, with alternative measures of wage inequality providing a robustness check. Section 6 is devoted to concluding remarks and consideration of the policy implications of the main findings.

\section{THEORETICAL FRAMEWORK AND PREVIOUS EMPIRICAL ANALYSES}

Previous research indicates that the most important source of increasing labour market inequality derives from a widening in the dispersion of wages and from the growth of nonwage incomes associated with self-employment and entrepreneurial activities. Aghion and Commander (1999) argue that both between-group and within-group inequality have increased as a result of changes in the relative demand for skilled and unskilled labour in transition countries. The leading explanations for this change areis trade liberalisation and 
skilled-biased technological change, in both of these cases FDI is likely to play a key causal role.

According to the conventional explanation, shifts in labour demand towards skilled play an important role in explaining the widening earnings dispersion. Among the main factors driving these demand shifts is technological change (Acemoglu and Autor, 2011). Snower (1999) argues that one should look for major structural changes affecting economies over the past two decades in order to explain the relative demand shift for skills. Previous research generally attributes increased wage inequality in developed countries primarily to increases in the relative demand for high-skill versus low-skill labour as a consequence of the skilledbiased technological change (Prasad, 2002). Keane and Prasad (2006) indicate that in the case of transition countries the increased wage inequality as a result of increased wage premium for college educated workers during the transition can reflect two situations. First, due to skill-biased technological changes workers now have better opportunities for matching with their most productive activities, so the skills generated by education became more productive. Second, the end of wage compression as market forces induce wages to become more closely aligned to labour productivities.

The impact of skill-biased technological change on wage inequality has been explained using the theoretical framework of Aghion and Howitt (1998) and Aghion and Commander (1999) where wage inequality is examined in a model of a general purpose technology (GPT). This is a model of major technological change through social learning: a process where firms learn to adopt a new technology or organizational form through observing the experience of other firms using it. This model is likely to be particularly appropriate to transition countries experiencing a rapid inflow of FDI. At the beginning of the transition period wage inequality increases due to the increased demand and wages for skilled labour, however in the later phase, wage inequality may decrease as the supply of skilled labour may increase, which in this model is explained through the two phases of GPT. The GPT theoretical framework has been used by Figini and Görg (2011) to analyse the relationship between FDI and wage inequality and to test whether the effect of FDI on wage inequality is non-linear in a crosscountry context and it is incorporated into the empirical specification employed below. Figini and Görg suggest that the relationship is non-linear, with the effect of FDI on wage inequality depending on the level of economic development of countries. In developing countries (which includes the transition economies) wage inequality increases (albeit at a decreasing rate) with the FDI stock, which is in line with the inverted-U pattern for the relationship between FDI and wage inequality. Mahutga and Bandelj (2008) discuss the question of how FDI affects inequality using the Gini index as their measure of inequality (calculated from household earnings). They expect FDI to contribute to rising inequality by increasing wage inequality between management and labour within the foreign sector. Their results indicate that foreign investment has a positive effect on income inequality in CEE, no matter how FDI is measured. FDI increases inequality between management and labour within the foreignowned sector, and between foreign and domestic sectors, where foreign-owned firms pay higher wages relative to domestic ones. They tentatively conclude that inwards FDI is a powerful determinant of the behaviour of income inequality in transition countries.

The argument that increasing trade openness is linked to increases in wage inequality was initially examined through the Hecksher-Ohlin and Stolper-Samuelson models. According to the Stolper-Samuelson model, free trade would raise the incomes of the abundant factors of production and lower the returns to the scarce factors of production (Jensen and Rosas, 2007). This model in the simplest $2 \times 2$ version predicts that countries abundant in unskilled labour 
will specialise in unskilled-labour-intensive products. Therefore trade liberalisation should increase the price of the intensively used factor (i.e. unskilled labour) and decrease the price of the skilled-labour intensive imported products and hence decrease the wages of domestic skilled labour (Goldberg and Pavcnik, 2007), leading to decreasing wage inequality. Hence, in developing and some transition countries abundant with unskilled labour, according to this theory production and/or exports should be concentrated in unskilled labour--intensive sectors, increasing the relative demand for unskilled labour and decreasing inequality between skilled and unskilled workers. However, there is little evidence in the literature that directly supports the HO and Stolper-Samuelson theorems (Higgins and Williamson, 1999; Goldberg and Pavcnik, 2007; Meschi and Vivarelli, 2007). Krugman (2008) argues that this may be a result of the short period of data covered in some studies (up to 5 years). According to Goldberg and Pavenik (2007), most of the studies that do support HO and StolperSamuelson theorems and find that exporting sectors in developing countries were less skillintensive than the import-competing sectors, only cover the period until mid-1980s and do not distinguish between higher-skilled and lower-skilled trading partners for each developing country. If a country is an exporter of skill-intensive products and an importer of goods produced by low-skilled labour, trade liberalisation with developing countries will increase the effective supply of goods produced by low-skilled labour (Topel, 1997). These goods will have lower prices in the international market which implies a reduction in the domestic production of goods produced by low-skilled labour and probably leading to rise in wage inequality. As increased trade openness shifts production toward specialisation on the basis of comparative advantage in skill-intensive products then the elasticity of substitution in production between high-skill and low-skill labour becomes the key parameter. If the substitution between high-skill and low-skill workers is more inelastic, then even a small increase in the share of imports in aggregate income may have a large impact on wages, i.e. increasing wage inequality, but if substitution is more elastic, then increased trade is unlikely to cause greater wage inequality.

Kuznets (1955) posed the hypothesis that inequality increases in the early stages of economic development and decreases after a certain average income is attained. His empirical evidence suggested that income inequality is increasing in the early phases of industrialisation and urbanisation, when the agricultural and rural sector dominates in the economy. Discussing the movement from agricultural to the industrial sector and from rural to urban locations Kuznets argues that rural population has a lower average income per capita compared to urban population and lower income inequality. In the early phase of economic development the gap between the rural and urban average per capita income will increase, because the industrial productivity in urban areas increases more rapidly. This will initiate migration from rural to urban areas contributing to increases in the economy's overall degree of inequality as a result of a rise in per capita income of the persons who move. However, this movement depresses urban wages and raises relative wages in rural areas as a result of the decreasing size of the agricultural labour force. Kuznets (1955) argues that after the early stage of industrialisation and urbanisation and the increase in the 'native' urban population, i.e. population which is born in cities rather than in rural areas, the income share of the lower-income groups of the urban population will rise. The 'native' population is more capable of using the economic and political possibilities of the city and securing higher income shares, than the people immigrating from the countryside or abroad, and this decreases overall income inequality. However, Kuznets in this study does not fully explain the demographic, political and social factors that could contribute to the decline in the shares of the lower income groups and technical change is neglected (Aghion and Howitt, -1998). 
However, as Peter (2003) argues, it is not yet clear to what extent cross-country differences in returns to skills are driven by: technological change; changes in the education and experience premia; globalisation factors; country-specific wage determination processes and other institutional rigidities. The increased earnings inequality in transition countries was in part attributable to increases in the education premium and to the growth of within-sector inequality as a result of market liberalisation and institutional changes. As Galor and Moav (2000) argue, the rise in skill-biased technological change raises the rate of return to skill. This increase in the return to skills stimulates an increase in the supply of educated labour, dependent upon the size of the wage-elasticity of the supply of skilled labour, which leads to a further increase in the rate of technological progress. The increase in the level of human eapital and technological progress can lead to a monotonic rise in wage inequality, both within and between groups along the transition to a steady-state equilibrium (Galor and Moav, 2000).

In transition economies, given the lack of effective technology transfer from their R\&D sector to industry, technological change is determined mainly by technology diffusion from trade and FDI across borders (Gurbiel, 2002; UNCTAD, 2003; Keller, 2004). Considering that foreign-owned firms typically use more advanced technologies, their entrance will create changes in the composition of jobs by increasing the demand for skills and more educated workers and raising the skill premium. Accordingly foreign-owned firms will typically pay higher wages than domestic owned firms and increase wage inequality between groups. The increased demand for a skilled and more educated labour force which results in a higher skill premium and higher returns to education should increase the incentive for investing in education, hence in the long-run increase the supply of skills and more educated workers and offset the increased wage inequality (Galor and Moav, 2000). Given that wages are the main source of income in transition countries, it is expected that changes in wage inequality drive ehanges in income inequality in these countries. For this reason and given the scarcity of previous relevant research on the role of FDI, both wage and income inequality studies are reviewed. Firstly, cross-country analyses on the effect of FDI and trade on wage inequality and income distribution are reviewed. Secondly, the focus shifts to single country studies of the effects of FDI on wage inequality.

Transition countries experienced a sharp increase in unemployment (especially amongst lesseducated groups), especially in the countries of South Eastern Europe (KILM, 2015 ${ }^{1}$ ). As a result of structural changes unemployment increased sharply during the initial transition period in most of these countries. According to the Aghion and Blanchard (1994) model, this occurred mainly as a result of the closure of state enterprises. The movement of labour from the state to the private sector involved a rise in unemployment and change in wages. The private sector creates jobs but sets wages according to market conditions. When the state sector is decreasing, unemployment increases competing wages down. This should help the private sector create new jobs, but higher unemployment leads to higher taxes per employed worker, since the state typically provides unemployment benefits which leads to a decrease in private job creation. Biewen and Juhasz (2010) argue that this rising unemployment increased personal income inequality because unemployment benefits are usually lower than the former wage incomes. The contribution of unemployment to wage inequality will be larger if more unemployment growth is concentrated in the lower part of the income distribution, in line with the hypothesis that skill-biased technological progress especially affects the employment prospects of low-skilled worker.

\footnotetext{
${ }^{1}$ Key Indicators of the Labour Market (KILM from ILO), data extracted on 12.11.2017.
} 
Most of transition countries are characterised by low or no safety nets in terms of benefits. This may affect the distribution of wages by lowering the wages of less skilled workers contributing to increases in wage inequality (Boeri and Terrell, 2002). To capture institutional differences in the labour market the Index of Economic Freedom (IEF) is included in the wage inequality model. The relationship between the IEF and wage inequality is expected to be positive since higher values of this index for a country imply less interference in the market, for example a weaker influence of unions and minimum wage legislation, leading to higher wage inequality ${ }^{2}$.

Bruno et al. (2004) analyse whether FDI has contributed to a rise in earning inequality and to the change in the skill composition of labour demand in Poland, Hungary and the Czech Republic, the three European transition economies with the largest FDI inflows during the 1990s. They use industry-year panel data for six sectors for the period 1993-2000. To proxy FDI penetration they use the inward FDI stocks. Earning inequality and composition of labour demand are proxied by the skilled labour shares of the total wage-bill and total employment. To account for other possible factors influencing wage inequality they include business enterprise expenditure on R\&D (as a proxy for the influence of technical progress), exports and imports of final goods to account for the effects of international trade on relative factor prices and to control for industry-scale effects they include gross value added. Their results suggest that FDI has not worsened wage inequality through labour demand shifts, but it has contributed to raising the skill-premium. Hence, they conclude that multinational firms affect the transition restructuring process mainly by favouring workers mobility across sectors and occupations. In addition, they claim that FDI brings wage dispersion closer to the actual skill distribution, rather than influencing the composition of labour demand.

Mahutga and Bandelj (2008) discuss the question of how FDI affects inequality using the Gini index as their measure of inequality (calculated from household earnings). They expect FDI to contribute to rising inequality by increasing wage inequality between management and tabour within the foreign sector. They control for the size of the private sector, government spending, unemployment, and three measures of foreign investment. They use longitudinat data for ten Central and East European post-socialist countries, for the time from 1990 to 2001. Their results indicate that foreign investment has a positive effect on income inequality in CEE, no matter how FDI is measured. FDI increases inequality between management and tabour within the foreign-owned sector, and between foreign and domestic sectors, where foreign-owned firms pay higher wages relative to domestic ones. They tentatively conclude that inwards FDI is a powerful determinant of the behaviour of income inequality in transition countries.

France and Gerussi (2010) analyse the effects of trade and inward FDI on income distribution in 18 transition economies during the period 1990-2006. They use the FE method to account for individual country heterogeneity and potential misspecifications. Since inequality may be persistent across time and dependent on factors that change slowly, they include the lagged

\footnotetext{
${ }^{2}$ In addition to this index, Fredom House and Polity IV were used as a democracy measure. Since polity2 (from Polity IV) and PR (Political Rights) and CL (Civil Liberties) are highly correlated (0.8 and 0.9) they were included in separate regressions. Whilst they had the expected sign, i.e. greater democracy freedom leading to greater wage inequality, they were not significant and their inclusion had no significant effect on coefficients of the other variables. To choose between fixed effects model and random effects model the Hausman's ChiSquare statistic was used. The test suggests that random effects could not be estimated, except when including the CL in the model. Results are available upon request.
} 
Gini in the second step. This creates problems of endogeneity since the lagged dependent variable is probably correlated with the error term and they use the one step SYS-GMM estimator Results indicate that FDI does not seem to have a significant effect on income inequality, whereas increased trade leads to an initial increase in the Gini index value, which decreases as trade flows increase.

Figini and Görg (2011) also analyse the relationship between FDI inflows and wage inequality. For this purpose, they include 103 countries in their sample, dividing them inte developed (OECD) countries and developing (non-OECD) countries, for the period 1980 to 2002. Following Aghion and Howitt (1998), they use an endogenous growth model where wage inequality is examined in a model of general purpose technology (GPT). To measure wage inequality they use the Gini and Theil indices for each country year. Figini and Görg suggest that the relationship is non-linear, with the effect of FDI on wage inequality depending on the level of economic development of countries. In developing countries (which includes the transition economies) wage inequality increases (albeit at a decreasing rate) with the FDI stock, which is in line with the inverted- $U$ pattern for the relationship between FDI and wage inequality.

Looking at firm-level studies, Earle and Telegdy (2007) address the question of publicprivate and foreign-domestic wage differentials for the period from 1986 to 2003 in Hungary. To examine the impact of ownership on wages they estimate different specifications, but the results indicate that a fixed-effects specification is preferred to the OLS and a specification with trends to one without trends. They find a significant wage premium for state and foreign ownership, compared to domestic private ownership. In addition, they control for worker (such as education, experience, gender, and oceupation) and firm characteristics (size, industry, and productivity) and find that ownership type is highly correlated with these eharacteristics. Their results suggest that the substantial unconditional wage differentials are explained mostly by the differences in worker and firm characteristics. The results indicate a small difference between the unconditional estimates and those controlling for workers eharacteristics, even though worker characteristics are highly correlated with both wages and ownership. Adding firm characteristics further diminishes the magnitude of foreign and state eoefficients. They conclude that there may be no difference in the wage behaviour of foreignowned and state-owned firms. However, they do not give a clear explanation for their finding of only a small difference between the unconditional estimates and those controlling for workers characteristics, even though worker characteristics are highly correlated with both wages and ownership.

Jensen (2009) investigates foreign subsidiaries' performance and market efficiency effects in Poland during the period 1993-2004. In analysing the direct and indirect effects of FDI she uses firm-level panel for manufacturing sector estimating total factor productivity, labour productivity, employment growth, mark up levels and profitability. To account for cross section dimension FGLS is used, which allows for an error term component that is heteroscedastic or specific to each firm. The findings suggest that foreign subsidiaries in Poland pay higher wages and achieve higher employment growth relative to their domestic eounterparts.

Eriksson and Pytlikova (2011) examine the relationship between wages, labour productivity and ownership in the Czech Republic using a linked employer-employee dataset. Analysing employees' characteristics they find that foreign-owned firms on average employ younger workers with shorter tenure, have almost twice as large a share of foreign employees and a higher share of female employees. However, there are no significant differences in 
employment by the level of education or in the share of white-collar employees. In addition, foreign-owned firms are concentrated in manufacturing industry and located mainly in the eapital city. Firm level analyses, where the dependent variable is the average firm wage, imply that the raw difference in average wages between foreign and domestic-owned firms is 23.6\%. This premium remains when they account for differences in the compositions in firms' workforces (age and firm tenure, share of female employees and employees with foreign citizenship, and employees' educational qualifications). After controlling for region, industry and firm size the raw difference in average wages between foreign and domesticowned firms reduces to $16.2 \%$. However, analysis based on the units of observation being individual employees, suggest that the unconditional foreign ownership premium is $7 \%$, eonsiderably lower than those derived from the firm level analysis. In addition, the gap in tabour productivity between foreign and domestic-owned firms is more than twice the size of the wage gap. Adding human capital variables increases the wage differential to $14 \%$. However, this study does not provide any explanation of the empirieal methodology used.

To conclude, there is some empirical evidence suggesting that there is a positive the relationship between FDI stock and wage inequality in transition economies, her relationship is likelyappears to be a complex one. FDI and trade liberalisation seem to-raise the demand and wages for more educated and skilled workers, hence increasing wage inequality between skilled and unskilled workers. Firm level-mpirical stulies generally findEmpirical evidence suggests that foreign-owned firms pay higher wages relative to domestic ones. In part, these differences in wages can be explained by differences in worker characteristics, such as education, skills, age and gender, ethnicity, occupation and the differing wage returns for those skills (Earle and Telegdy, 2007; Jensen, 2009; Eriksson and Pytlikova, -2011).

\section{MODEL SPECIFICATION, DATA AND DESCRIPTIVE STATISTICS}

Jensen and Rosas (2007) argue that one should approach the analysis of the determinants of wage inequality very carefully since potential issues of reverse causality, selection bias, and omitted variables can lead to spurious results. Accordingly, several model specifications and tests are used to check for the robustness of the results. Due to missing data this study is using unbalanced panel data for up to nineteen transition countries and a fixed effects model to account for the presence of unobserved heterogeneity across countries and potential endogeneity of FDI with wage inequality.

Following the above review of theoretical and empirical studies the following basic equation is specified:

$$
\text { Inequally }_{i t}-\beta_{0}+\beta_{1} F D I_{i t}+\beta_{2} F D I_{i t}^{2}+\beta_{3} X_{i t}+\lambda_{t}+t_{i t}
$$

where $i$ indexes countries, and $t$ the time period. Inequality is a measure of wage inequality, for each country-year. The stock of FDI is chosen rather than the inflow in order to reflect the long-term effects, since FDI stocks contribute to the stock of general-purpose technology available in the economy (Figini and Görg, 2011). The previous discussion indicated that FDI may increase labour market inequality by increasing the relative demand for skilled labour and raising the skilled wage premium. However, as FDI increases in a country it may reduce wage inequality in the long run, as a result of the increased supply of skilled labour force. To 
control for this possible non-linear effect of inward FDI the squared term of FDI is added in the wage inequality equation.

$X$ is a vector of control variables deduced from the discussion above; $\lambda$ is a full set of time dummies and $e$ is the error term. Domestic investment and R\&D expenditure as a percentage of GDP are introduced as a proxy for technological change. The higher these rates, other things equal, the faster the rate of skill-biased technological progress, thereby increasing the proportion of skilled workers and hence the wage differential between skilled and unskilled workers._Dadres and Ginther (2001) provide some evidence from the US that technology is a significant, but not dominant, determinant of between and within-group earnings inequality. Accordingly ${ }_{2}$ the expected sign of the domestic investment and $R \& D$ variables is positive. In addition, an openness variable (the sum of imports and exports as a share of GDP) is included in the model to control for the effect of increased trade volumes on wage inequality. With respect to trade openness $H-O$ theory suggests that greater openness to trade should reduce wage inequality in developing countries by increasing the relative demand for unskilled tabour and narrow the wage gap between skilled and unskilled workers. However, empirical studies such as Peter (2003), Onaran and Stockhammer (2008) and Lechthaler and Mileva (2014) indicate that trade liberalisation can inerease the wage differential be ween skilled and unskilled workers as a result of an increase in the returns to skilled labour._Increases in GDP per capita should be associated with reductions in wage inequality as suggested by the Kuznets hypothesis. In order to test for the influence of the supply side of the labour market measures of the level of education of the labour force are included. Other things being equal, an upward shift in the supply of more educated/skilled workers should depress the skill premium and lower wage inequality between skilled and unskilled workers. The rate of unemployment and institutional differences are also controlled for in the model. Most of transition countries are characterised by high unemployment rates and low or no safety nets in terms of benefits. This may affect the distribution of wages by lowering the wages of less skilled workers contributing to increases in wage inequality (Boeri and Terrell, 2002). To eapture institutional differences in the labour market the Index of Economic Freedom (IEF) is included in the wage inequality model. The relationship between the IEF and wage inequality is expected to be positive since higher values of this index for a country imply less interference in the market, for example a weaker influence of unions and minimum wage legislation, leading to higher wage inequality.

Wage inequality is commonly measured by the GINI coefficient which ranges from 0 to 1 , where 0 represents complete equality (all individuals receive equal wages) and 1 represents the highest level of inequality. The Gini coefficient utilised is the distribution of earnings, which refers to monthly wages with bonuses, for full-time employees as reported by employers. Gini coefficients (labelled as GINI) were obtained from the TRANSMONEE (2010) database. Using the GINI variable as a dependent variable equation 1 can be estimated for the period 1993 to 2008 for 19 transition countries ${ }^{3}$, however due to missing data the sample has 195 GINI observations. This measure is widely used in the empirical investigation of inequality even though it is not necessarily the best measure of wage inequality and certainly not of labour market inequality. There are significant cross-country differences in the collection of income data which is likely to introduce systematic and random errors in the data, decreasing the usefulness of the Gini coefficient. Given these limitations an alternative measure of wage inequality is also used: the Theil coefficient.

\footnotetext{
${ }^{3}$ Albania; Azerbaijan; Bulgaria; Czech Republic; Estonia; Georgia; Hungary; Kazakhstan; Kyrgyzstan; Latvia; Lithuania; Macedonia; Moldova; Poland; Romania; Russia; Slovakia; Slovenia and Ukraine.
} 
THEIL's T statistic, measured across sectors within each country also measures the evolution of wage-inequality. If every individual has exactly the same income, $\mathrm{T}$ will be zero; this represents perfect equality and is the minimum value of THEIL's T. If one individual has all of the income this represents the highest inequality and is the maximum value of Theil's $\mathrm{T}$ statistic. The advantage of Theil's T statistic is that one can use group level data since individual data are not always available. Data come from the UTIP-UNIDO (2005) database. Data on THEIL coefficient for the set of countries in our sample are very limited. So, the period of estimation with this measure of wage inequality is from 1990 to 2002 and with missing values the sample has 139 observations and 15 countries ${ }^{4}$. Table 1 presents the summary statistics of the variables included in the regressions.

Table 1. Summary statistics of the variables of interest, GINI:1993-2008; THEIL: 1990-2002

\begin{tabular}{|c|c|c|c|c|c|c|c|}
\hline Variable label & $\begin{array}{l}\text { Variable } \\
\text { name }\end{array}$ & $\begin{array}{l}\text { Expected } \\
\text { sign }^{5}\end{array}$ & Mean & $\begin{array}{l}\text { Std. } \\
\text { Dev. }\end{array}$ & Min & Max & $\begin{array}{l}\text { Number } \\
\text { of Obs. }\end{array}$ \\
\hline Gini & GINI & & 0.36 & 0.07 & 0.23 & 0.52 & 195 \\
\hline Theil & THEIL & & 0.05 & 0.06 & 0.004 & 0.36 & 139 \\
\hline FDI stock ( $\%$ of GDP) & FDI &,+- & 21.92 & 16.51 & 0.36 & 85.86 & 188 \\
\hline $\begin{array}{l}\text { Domestic Investment ( } \% \\
\text { of GDP) }\end{array}$ & DOM & + & 17.47 & 5.16 & 1.84 & 29.79 & 193 \\
\hline $\begin{array}{l}\text { Research and } \\
\text { development } \\
\text { expenditure ( } \% \text { of GDP) }\end{array}$ & $\mathrm{R} \& \mathrm{D}$ & & 0.61 & 0.33 & 0.17 & 1.62 & 135 \\
\hline Trade $(\%$ of GDP) & TRADE & $?$ & 97.64 & 27.67 & 44.25 & 172.79 & 195 \\
\hline GDP per capita & GDP &,+- & 7705.12 & 5401.928 & 1003.97 & 29574.1 & 193 \\
\hline $\begin{array}{l}\text { Tertiary school } \\
\text { enrolment (\%) }\end{array}$ & EDU & - & 41.92 & 18.33 & 11.64 & 86.71 & 169 \\
\hline $\begin{array}{l}\text { Labour force with } \\
\text { tertiary education }(\%)\end{array}$ & LFEDU & - & 21.82 & 13.98 & 2.4 & 66.1 & 88 \\
\hline Unemployment rate & UN & + & 11.54 & 6.73 & 3.9 & 37.3 & 183 \\
\hline $\begin{array}{l}\text { Index of Economic } \\
\text { Freedom }\end{array}$ & IEF & + & 55.37 & 9.11 & 30 & 76.1 & 150 \\
\hline
\end{tabular}

The inward FDI stock as a percentage of GDP (FDI) is used to identify the effect of inward FDI on wage inequality. To account for depreciation this variable is measured as the value of the share of their capital and reserves (including retained profits) attributable to the parent enterprise, plus the net indebtedness of affiliates to the parent enterprises. Data on FDI are obtained from UNCTADSTAT (2011). Domestic investment (DOM) is defined as the gross fixed capital formation as a percentage of GDP, after deducting the FDI inflow. Both the gross fixed capital formation (\% of GDP) and FDI inflow (\% of GDP) are taken from the World Development Indicators (WDI, 2010) available from the World Bank. R\&D is research and development expenditure (\% of GDP) obtained from World Development Indicators (WDI, 2017). TRADE is the sum of exports and imports of goods and services measured as a

\footnotetext{
4 Albania; Armenia; Azerbaijan; Bulgaria; Croatia; Hungary; Kyrgyzstan; Latvia; Lithuania; Moldova; Poland; Romania; Russia; Slovenia and Ukraine.

${ }^{5}$ Where $(+,-)$ indicates the expected non-linear effect of the variable on wage inequality, whereas (?) indicates that the expected effect is ambiguous.
} 
share of GDP. Data on TRADE was obtained from World Development Indicators (WDI, 2010). The proxy for the level of economic development, the Gross Domestic Product (GDP) is based on purchasing-power-parity (PPP) per capita GDP in current international dollars to take into account the price differentials across countries. Data was obtained from International Monetary Fund (IMF), World Economic Outlook Database (2010). In addition, two proxies for education are used, EDU and LFEDU. EDU is defined as the tertiary school enrolment as a percentage of gross enrolment ratio, which is the ratio of total enrolment regardless of age, to the population of the age group that officially corresponds to the level of tertiary education. Data for this proxy were obtained from World Development Indicators (WDI, 2010). Enrolment rates may not be the best proxy for the level of education of the labour force, a better proxy would be the educational qualifications of the current workforce. The World Development Indicators (WDI) and Global Development Finance (GDF) provide information on the percentage of the labour force with tertiary education (LFEDU), but as can be seen in Table 1 there are many missing values, therefore both proxies are used. Data on the unemployment rates a percentage of total labour force (UN) come from the $I M F$, World Economic Outlook Database (2010). The proxy for institutions is the Index of Economic Freedom (IEF) published by The Heritage Foundation (2011).

\section{EMPIRICAL METHODOLOGY}

Following the conventional procedure for panel data, the Ordinary Least Squares (OLS), Fixed Effects (FE) and Random Effects (RE) models have been compared. As explained below, the appropriate estimator seems to be the FE model. To check if the model is misspecified diagnostic tests have been applied. The common problems associated with panel estimations such as slope homogeneity, cross-sectional dependence in the error, groupwise heteroscedasticity, serial correlation in the errors and normality of the errors have been investigated. These tests are explained below. Robust standard errors are used to account for the heteroscedasticity problem. First, to check for the non-linearity of FDI the FE model was estimated introducing the squared term of FDI. Second, three additional explanatory variables, R\&D expenditures as a percentage of GDP, labour force with tertiary education and the Index of Economic Freedom were introduced into the model. These three variables were not included in the first specification since they reduce significantly the number of observations. Moreover, the possibility of spurious regression was investigated, unit root tests were undertaken to check if the variables are stationary. Some cross sections for some variables have very short time dimensions and also missing values, whereas for small $\mathrm{T}$, panel unit root tests have low power and there is the potential risk of concluding that the whole panel is nonstationary even when there is a large proportion of stationary series in the panel (Baltagi, 2005). Since the main variables of interest (GINI and FDI) are stationary and given that the potential danger of spurious regression in the case of a unit root if the model had non-stationary variables on both the left and right--hand sides, the empirical analysis proceeded under the assumption that there is no unit root in the panel ${ }^{\underline{6}}$. As a robustness check the estimates of the basic equation were replicated by using the THEIL coefficients as the dependent variable. In addition, to control for the time-varying trend the test for common factor restrictions (CFR) was conducted allowing modelling the unobserved components when using THEIL.

FE is the preferred model and it is likely to have better small sample properties than a random effects model and can be estimated for unbalanced panels as is the case here. The fixed

${ }^{6}$ See Appendix 1 for more details on the unit root tests. 
effects model has constant slopes but intercepts differ according to the cross-sectional group, i.e. by country, allowing for individual country heterogeneity and accounting for potential omitted variables and misspecification. In the fixed effects (LSDV) model the effects of explanatory variables are estimated only from within-group variation (Greene, 2002). The basic static wage inequality model is estimated with period dummy variables, in order to minimise the cross-country correlation in the error terms arising from economic cycle effects as a result of the transition process. It is a key estimation issue whether FDI should be considered as an endogenous variable. Inward FDI flows at the national level are hypothesised to be determined by international differences in the return to capital, which are largely exogenous to local labour markets (Feenstra and Hanson, 1995). However, the possibility that wage inequality is a determinant of FDI cannot be excluded. The problem of inverse causality could occur since FDI may disproportionately locate to areas characterised by a higher level of inequality (Franco and Gerussi, 2010). One commonly used method to deal with the endogeneity problem is the GMM estimator (Arellano and Bond,1991, Arellano- and Bover, 1995 and /Blundell and Bond, 1998). Roodman (2006) argues that this is an appropriate approach for situations with small $\mathrm{T}$, large $\mathrm{N}$ panels, with independent variables that are not strictly exogenous, meaning that they may be correlated with past and possibly current realizations of the error; with fixed effects; and with heteroskedasticity and autocorrelation within individuals. This is not the case in this study since $\mathrm{T}$ and $\mathrm{N}$ are close to each other $(\mathrm{T}=16, \mathrm{~N}=19)^{7}$. Another way of dealing with the potential endogeneity problem is to use instrumental variables (IV) methods. However, finding a good instrumental variable for an endogenous explanatory variable is very difficult given the limitations of the available data. Under the assumption that the correlation of FDI with the error term is fixed over time, controlling for country fixed effects alleviates the problem of potential endogeneity (Figini and Görg, 2011).

Diagnostics for panel analysis are not well developed, especially for unbalanced and small panels. However ${ }_{2}$ the available diagnostic testing can provide some useful indicators, therefore diagnostics have been applied to the chosen FE model both in levels and log-linear form. The second approach is preferred since on checking for normality the test and the plot of residuals indicate the presence of non-normality in levels and serial correlation is also improved with logs.

The results suggest no slope homogeneity, heteroscedasticity, serial correlation and the residuals are normally distributed. The problem of heteroscedasticity and serial correlation is addressed using Driscoll-Kraay standard errors. Given that the unobservable common factors are uncorrelated with the explanatory variables, the coefficient estimates from the FE estimator are still consistent but inefficient and the standard error estimates of commonly applied covariance matrix estimation techniques are biased. Driscoll and Kraay (1998) propose a nonparametric covariance matrix estimator that produces heteroskedasticity- and autocorrelation-consistent standard errors that are robust to general forms of spatial and temporal dependence (Hoechle, 2007).

To improve the statistical characteristics of the FE model and to test for non-linearity of FDI the squared term of FDI stock (SQFDI) has been introduced. Applying diagnostic tests to this

\footnotetext{
${ }^{7}$ A GMM estimator is used only as a robustness check and the preferred model is Fixed Effects. The system GMM estimator seems to be consistent since there is no second-order serial correlation in the residuals (AR2 statistic, $\mathrm{p}=0.32$ ) and the Sargan test shows that there are no problems with the validity of the instruments used $(p=0.99)$. However, the results indicate that only the lagged Gini and unemployment are significant.
} 
model the results indicate that a heteroscedasticity problem is still present ${ }^{8}$, there is no slope homogeneity or first order autocorrelation and residuals are normally distributed. In order to further control for the effect of technological change and education on wage inequality, an alternative measure of technological change and education is added to the model, namely the R\&D as a percentage of GDP and the proportion of the labour force with tertiary education (LFEDU). Additionally, the Index of Economic Freedom (IEF) is included to control for institutional differences. This model is estimated with and without the squared term of FDI stock. The number of total observations when including LFEDU and IEF is reduced from 157 to 70 , therefore these results are used primarily as a robustness check. For comparison the estimates of the basic equation are replicated by using THEIL coefficients in log-linear form to account for non-normality of the distribution of residuals ${ }^{9}$.

If the unobserved components that create interdependencies across cross-sections are correlated with the included regressors, fixed effects estimators will be biased and inconsistent (Hoyos and Sarafidis, 2006). Even though the tests suggested that there is zero cross dependence in the errors, for the reasons indicated above the fixed effects regression with $\operatorname{AR}(1)$ disturbances was estimated. $\mathrm{AR}(1)$ is the correct specification only if common factor restrictions hold (CFRs). The test on common factor restrictions is performed both in the OLS regression and in the FE regression. In the OLS estimation the coefficient on the lagged dependent variable is subject to maximum upward bias, whereas in fixed effects estimation the coefficient on the lagged dependant variable is subject to maximum downward bias (Roodman, 2009). The CFRs indicate that there might be some information missing in the specification, e.g. dynamics in the model, however it is not known from which variable they derive. Hence, if they are not accounted in the model they are in the residual. Accordingly, if the CFRs hold in both estimations the model can be estimated with AR(1) correction. Results indicate that in the OLS estimation the CFRs hold, but in the FE regression CFRs do not hold for DOM, TRADE, UN and IEF. Hence, the AR(1) is not applied when using GINI as dependent variable. As in the case with the GINI coefficients, the test for CFR is conducted allowing modelling with the AR(1) correction when using THEIL as the dependent variable. However, the CFR test could not be performed including all variables since there are not enough observations in this case, so LFEDU and IEF are not included in the test.

\section{RESULTS}

This section presents estimation results based on the three alternative measures of wage inequality. Table 2 presents the results of estimating equation (1) in $\log$ form with the GINI coefficients as the dependent variable. Columns (1) and (2) provide results for regressions of FE using Driscoll-Kraay standard errors, respectively including the simple FDI term and the quadratic specification. In column (3) the alternative proxy for technological change is included (R\&D) in addition to DOM. Columns (4) and (5) replicate the estimations adding LFEDU and IEF in the model, with and without SQFDI, however excluding R\&D. In the case of using the THEIL coefficients as a measure of wage inequality, Table 3 reports the results of FE using Driscoll-Kraay standard errors and the results of AR(1) correction.

\footnotetext{
${ }^{8}$ As above this problem is addressed using Driscoll-Kraay standard errors.

${ }^{9}$ Using Theil data $(\mathrm{T}=13$ and $\mathrm{N}=14)$ the appropriate estimator seems to be the FE model since there are only 95 observations and including all variables leaves only 30 observations and 8 groups. Testing the hypothesis that the coefficients of the variables are jointly equal to zero there is insufficient evidence to reject $\mathrm{H}_{0}$ ( $\mathrm{p}$ value is 0.3 ), this model is estimated without time dummies to avoid the loss of degrees of freedom.
} 
Overall, the results indicate a positive relationship between FDI stock and wage inequality in transition countries.

With GINI as the dependent variable, Table 2 indicates that the FDI coefficient (FDI stock as percentage of GDP) is positive and significant in the specifications in which the squared term of FDI is not included, and it is very similar in terms of magnitude, consistent with the finding of Franco and Gerussi (2010) and Figini and Görg (2011). This suggests that if the share of FDI in GDP increases by $1 \%$ wage inequality will increase for $0.05 \%$ (column 1 ); or by $0.06 \%$ including LFEDU and IEF in the model (column 4 ). There is no clear evidence of a concave relationship between FDI and wage inequality in transition countries, which may not be surprising considering that transition economies have not yet attracted high levels of FDI. The SQFDI is significant only in column (2) at 10\% level of significance.

The coefficients of DOM and R\&D do not have the expected sign and are significant at $5 \%$ in the regressions using all variables in columns (3) and (4) and (5). A higher rate of domestic investment, other things equal, should be associated with more capital-intensive and skillintensive production that should, other things being equal, increase inequality. However, the negative sign in this case may indicate that domestic investment in these transition economies are associated with less-capital and less-skill intensive production leading to reductions in wage inequality. The coefficient on trade is positive and significant at $1 \%$ and $5 \%$ when including all variables indicating that $1 \%$ increase in the share of trade in GDP raises wage inequality by $0.14 \%$. The coefficient of GDP per capita is negative and significant indicating that the higher is the level of development of the country the lower is the wage inequality. The impact of education seems to differ across different specifications. The EDU coefficients look very similar in terms of magnitude and statistical significance in columns (1), (2) and (3) suggesting that wage inequality increases as the education of the potential labour force increases which is contrary to the prediction of orthodox theory. However, as argued above, enrolment rates may not be the best proxy for the workforce's level of education since wage inequality is more likely to be affected by the level of education of the current, rather than future, workers. The results of the alternative measure of education (LFEDU) significant at $1 \%$ level of significance suggest that for $1 \%$ increase in LFEDU decreases wage inequality by around $0.05 \%$, in line with our theoretical framework. Unemployment is not significant in any specification. The last variable included in the model, IEF, has the expected positive sign and is significant at $1 \%$ suggesting that, as anticipated, greater economic freedom is associated, other things being equal, with greater wage inequality.

Table 2. Fixed effects regressions (dependent variable is GINI)

\begin{tabular}{|c|c|c|c|c|c|}
\hline & $\begin{array}{l}\text { Fixed } \\
\text { effects }\end{array}$ & $\begin{array}{l}\text { Fixed } \\
\text { effects }\end{array}$ & $\begin{array}{l}\text { Fixed } \\
\text { effects }\end{array}$ & $\begin{array}{l}\text { Fixed } \\
\text { effects }\end{array}$ & $\begin{array}{l}\text { Fixed } \\
\text { effects }\end{array}$ \\
\hline & (1) & (2) & (3) & (4) & (5) \\
\hline VARIABLES & GINI & GINI & GINI & GINI & GINI \\
\hline FDI & $\begin{array}{l}0.051 * \star \star \\
(0.015)\end{array}$ & $\begin{array}{l}0.026 \\
(0.018)\end{array}$ & $\begin{array}{l}0.040 \\
(0.065)\end{array}$ & $\begin{array}{l}0.065 * \star \star \\
(0.008)\end{array}$ & $\begin{array}{l}0.049 \star \star \\
(0.019)\end{array}$ \\
\hline SQFDI & & $\begin{array}{l}0.008 * \\
(0.004)\end{array}$ & $\begin{array}{l}-0.007 \\
(0.012)\end{array}$ & & $\begin{array}{l}0.005 \\
(0.005)\end{array}$ \\
\hline $\mathrm{DOM}$ & $\begin{array}{l}-0.029 \\
(0.021)\end{array}$ & $\begin{array}{l}-0.022 \\
(0.020)\end{array}$ & $\begin{array}{l}-0.027 * \star \\
(0.010)\end{array}$ & $\begin{array}{l}-0.062 * \star \\
(0.024)\end{array}$ & $\begin{array}{l}-0.055 * * \\
(0.022)\end{array}$ \\
\hline$R \& D$ & & & $\begin{array}{l}-0.098 * \star \star \\
(0.029)\end{array}$ & & \\
\hline TRADE & $\begin{array}{l}0.051 \\
(0.039)\end{array}$ & $\begin{array}{l}0.058 \\
(0.038)\end{array}$ & $\begin{array}{l}0.107 \star \star \\
(0.038)\end{array}$ & $\begin{array}{l}0.144 * \star \star \\
(0.025)\end{array}$ & $\begin{array}{l}0.138 * \star \star \\
(0.026)\end{array}$ \\
\hline GDP & $-0.231 * \star$ & $-0.204 * \star$ & 0.005 & 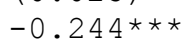 & 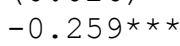 \\
\hline
\end{tabular}


The results where the THEIL coefficient is the dependent variable are reported in Table 3 . Again there is some evidence of a positive effect of FDI ( $\%$ of GDP) on wage inequality. Results indicate that a $1 \%$ increase in the share of FDI in GDP increases wage inequality by $0.2 \%$. The squared term of FDI ( $\%$ of GDP) is not significant, whereas in the AR (1) model only GDP, EDU and UN seem to be significant (column 3 and 4).

Table 3. Fixed effects regressions (dependent variable is THEIL)

\begin{tabular}{|c|c|c|c|c|}
\hline & $\begin{array}{l}\text { Drisc/Kraay } \\
\text { Std.Err. }\end{array}$ & $\begin{array}{l}\text { Drisc/Kraay } \\
\text { Std.Err. }\end{array}$ & $\mathrm{AR}(1)$ & $\mathrm{AR}(1)$ \\
\hline & $(1)$ & $(2)$ & (3) & (4) \\
\hline VARIABLES & THEIL & THEIL & THEIL & THEIL \\
\hline \multirow[t]{2}{*}{ FDI } & $0.229 * * *$ & $0.214 * \star \star$ & 0.167 & 0.118 \\
\hline & $(0.067)$ & $(0.053)$ & $(0.185)$ & $(0.244)$ \\
\hline \multirow[t]{2}{*}{ SQFDI } & & 0.017 & & 0.016 \\
\hline & & $(0.027)$ & & $(0.053)$ \\
\hline \multirow[t]{2}{*}{$\mathrm{DOM}$} & 0.391 & 0.440 & 0.152 & 0.166 \\
\hline & $(0.271)$ & $(0.281)$ & $(0.264)$ & $(0.270)$ \\
\hline \multirow[t]{2}{*}{ TRADE } & -0.235 & -0.340 & 0.068 & 0.046 \\
\hline & $(0.379)$ & $(0.481)$ & $(0.453)$ & $(0.462)$ \\
\hline \multirow[t]{2}{*}{ GDP } & -0.284 & -0.445 & $-1 \cdot 346 * \star *$ & $-1 \cdot 321 * \star \star *$ \\
\hline & $(0.564)$ & $(0.509)$ & $(0.349)$ & $(0.363)$ \\
\hline \multirow[t]{2}{*}{ EDU } & $0.588 *$ & 0.573 & $1.310 * \star \star$ & $1.263 * \star$ \\
\hline & $(0.315)$ & $(0.334)$ & $(0.467)$ & $(0.502)$ \\
\hline \multirow[t]{2}{*}{ UN } & $0.247 * *$ & $0.251 * *$ & $0.242 *$ & $0.249 *$ \\
\hline & $(0.088)$ & $(0.084)$ & $(0.135)$ & $(0.139)$ \\
\hline \multirow[t]{2}{*}{ Constant } & -4.068 & -2.375 & 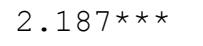 & $2.200 * \star \star *$ \\
\hline & $(3.792)$ & $(3.809)$ & $(0.414)$ & $(0.416)$ \\
\hline \multirow{4}{*}{$\begin{array}{l}\text { Observations } \\
\text { Number of groups } \\
\text { Number of index }\end{array}$} & 95 & 95 & 81 & 81 \\
\hline & 14 & 14 & & \\
\hline & & & & \\
\hline & & & 14 & 14 \\
\hline
\end{tabular}


All variables are in log form

Overall, the results are broadly consistent with previous findings and indicate that FDI increases labour market inequality by increasing the relative demand for skilled labour and raising the skilled wage premium. (Bruno et al., 2004; Earle and Telegdy; 2007; Jensen, 2009; Franco and Gerussi, 2010 and Figini and Görg, 2011). Increased trade also leads to an increase in the Gini index value suggesting that trade liberalisation can increase the wage differential between skilled and unskilled workers as a result of an increase in the returns to skilled labour, this is consistent with the findings- of Peter (2003), Onaran and Stockhammer (2008) and Lechthaler and Mileva (2014).

\section{CONCLUSION}

Using two alternative measures of wage inequality this paper has examined the effect of FDI on wage inequality in selected transition countries. Several model specification and tests have been used to obtain consistent estimates and to check for the robustness of the results. The results indicate that a rising share of FDI in GDP increased wage inequality in transition economies, though its overall effect was relatively small. This finding is consistent with those of most studies of this relationship in developed and developing countries (Hale and $\mathrm{Xu}$, 2016), though given the labour market conditions in ETEs the effect of FDI on wage inequality is relatively-weaker than anticipated. Results using GINI indicate that if the share of FDI in GDP increases by $1 \%$ wage inequality will increase by justfor $0.05 \%$. Considering the long run effect of FDI on wage inequality there is no clear evidence of a concave relationship between FDI and wage inequality in transition countries, which may not be surprising considering that few transition economies have, as yet, attracted high levels of FDI. There is also some evidence of a positive effect of FDI as a share of GDP on wage inequality using THEIL coefficients as a measure of wage inequality. Among the control variables some support for the Kuznets hypothesis is found, i.e. increases in GDP per capita are associated with reductions in wage inequality. In addition, there is no evidence for the $\mathrm{H}-$ $\mathrm{O}$ theory that greater trade openness reduces wage inequality. In line with the theoretical discussion, increases in the supply of more educated workers lowers wage inequality in transition economies.

In sum, the empirical evidence supports the hypothesis that an increased FDI inward stock as a share of GDP increases wage inequality in transition economies, however this relationship may be a complex one. Differences in average wages, wage differentials, employment shares of skilled workers and relative size of the foreign-owned sector are all likely to be important in determining for the overall behaviour of wage inequality. In addition, Whilst the distribution of FDI across industrial sectors may also explain the diversity of cross-country experiences since Bogliaccini and Egan (2017) found that FDI inflows to the service sector had the largest impact on raising inequality in middle income countries.

Consideration of the combined effects of FDI on labour markets in ETEs suggest that there are overall benefits. Productivity and wages increase as does the overall skill level of the labour force. The disproportional growth in the demand for skilled labour should over time induce current and future workers to invest in additional education and training. Thus, FDIs small effect on increasing wage inequality and any negative spillovers on domestic firms, $\underline{\text { such as a loss of skilled employees, are unlikely to warrant governments placing restrictions }}$ 
on inwards FDI. Policy-makers should instead consider addressing the causes of shortages in the supply of skilled labour. This may require targeted interventions supporting education and training providers and encouraging unskilled workers to retrain.

References:

Acemoglu, D. and Autor, D. (2011). Skills, Tasks and Technologies: Implications for Employment and Earnings. Handbook of Labour Economics, vol.4b, pp. 1043-1166.

Aghion, P. and Blanchard, O. (1994). On the Speed of Transition in Central Europe. NBER Macroeconomics Annual, vol.9, pp.283-330.

Aghion, P. and Commander, S. (1999). On the Dynamics of Inequality in the Transition. Economics of Transition, vol. 7, no.2, pp.275-298.

Aghion, P. and Howitt, P. (1998). Endogenous Growth Theory. The MIT Press. Cambridge, Massachusetts; London, England.

Arellano, M. and Bond, S. (1991). Some Tests of Specification for Panel Data: Monte Carlo Evidence and an Application to Employment Equations. The Review of Economic Studies, no. 58 , pp. $277-297$.

Arellano, M. and Bover, O. (1995). Another Look at the Instrumental Variable Estimation of Error Component Models. Journal of Econometrics, no.68, pp. 29-51.

Aristei, D. and Perugini, C. (2014). Speed and Sequencing of Transition Reforms and Income Inequality: A Panel Data Analysis. Review of Income and Wealth, series 60, no 3, pp. $542-570$.

Baltagi, B. (2005). Econometric Analysis of Panel Data. John Wiley and Sons, Chichester, England.

Biewen, M. and Juhasz, A. (2010). Understanding Rising Income Inequality in Germany. IZA Discussion Paper, no. 5062.

Boeri, T. and Terrell, K. (2002). Institutional Determinants of Labor Reallocation in Transition. The Journal of Economic Perspectives, vol. 16, no. 1, pp. 51-76.

Bogliaccini, J. and Egan, P. (2017). FDI and Inequality in Developing Countries: Does sector matter? Economics and Politics, vol. 29, issue 3, pp. 209-36.

Bruno, G., Crinò, R. and Falzoni, M. (2004). Foreign Direct Investment, Wage Inequality, and Skilled Labour Demand in EU Accession Countries. Universita' Deglistudi di Bergamo, Dipartimento di Scienze Economiche "Hyman P. Minsky”, Bergamo, Italy.

Dadres, S. and Ginther, D. (2001). Regional Research and Development Intensity and Earnings Inequality. Federal Reserve Bank of Atlanta, Economic Review. Second Quarter, pp. $13-26$. 
Earle, S. J. and Telegdy, Á. (2007). Ownership and Wages: Estimating Public-Private and Foreign-Domestic Differentials Using LEED from Hungary, 1986-2003. IZA Discussion Paper, no. 3125.

Eriksson, T. and Pytlikova, M. (2011). Foreign Ownership Wage Premia in Emerging Economies. Economics of Transition, vol.19, no.2, pp.371-395.

Estrin, S. (2017). Foreign Direct Investment and Employment in Transition Economies. Has FDI into Transition Countries had the Expected Economic Effects? IZA World of Labour, no.330.

Feenstra, R. and Hanson, G. (1995). Foreign Investment, Outsourcing and Relative Wages. NBER Working Paper, no. 5121.

Feenstra, R. and Hanson, G. (2001). Global Production Sharing and Rising Inequality: A Survey of Trade and Wages. NBER Working Paper, no. 8372.

Feenstra, R. and Hanson, G. (2003). Global Production Sharing and Rising Inequality: A Survey of Trade and Wages', in Kwan Choi \& James Harrigan (eds), Handbook of International Trade, New York, Basil Blackwell, pp. 617-868.

Figini, P. and Görg, H. (2011). Does Foreign Direct Investment Affect Wage Inequality? An Empirical Investigation. The World Economy, vol.34, issue 9, pp.1455-1475.

Franco, C. and Gerussi, E. (2010). Trade, FDI and Income Inequality. Empirical Evidence from Transition Countries. MIUR Working Paper Series, no.15.

Galor, O. and Moav, O. (2000). Ability-Biased Technological Transition, Wage Inequality, and Economic Growth. The Quarterly Journal of Economics, vol. 115, no. 2, pp.469-497.

Goldberg, P. and Pavcnik, N. (2007). Distributional Effects of Globalization in Developing Countries. Journal of Economic Literature, vol. 45, pp.39-82.

Greene, W. (2002). Econometric Analysis. Prentice Hall, New Jersey.

Gurbiel, R. (2002). Impact of Innovation and Technology Transfer on Economic Growth: The Central and Eastern Europe Experience. Warsaw School of Economics, Center of International Production Cooperation, July.

Hale, G. and Xu, M. (2016). FDI Effects on the Labour Markets of Host Countries, Federal Reserve Bank of San Francisco, Working Paper no. 2016-25.

Higgins, M. and Williamson, J. (1999). Explaining Inequality the World Round: Cohort Size, Kuznets Curves, and Openness. Federal Reserve Bank of New York, Staff Reports, no. 79.

Hoechle, D. (2007). Robust Standard Errors for Panel Regressions with Cross-Sectional Dependence. The Stata Journal, no.3, pp.281-312.

Hoyos, R. and Sarafidis, V. (2006). Testing for Cross-Sectional Dependence in Panel-Data Models. The Stata Journal, vol.6, no.4, pp.482-496. 
Jensen, C. (2009). Pay More, Earn Less, Work Harder- New Evidence on Foreign Subsidiary Performance and Market Efficiency in Emerging Markets. CASE, no.391.

Jensen, N. and Rosas, G. (2007). Foreign Direct Investment and Income Inequality in Mexico, 1990-2000. International Organization, vol.61, no.3, pp. 467-487.

Keller, W. (2004). International Technology Diffusion. University of Texas, National Bureau of Economic Research, Centre for Economic Policy Research. April.

Krugman, P (2008). Trade and Wages, Reconsidered. Presented in the meeting of the Brookings Panel on Economic Activity.

Kuznets, S. (1955). Economic Growth and Income Inequality. The American Economic Review, vol. 45, no.1, pp.1-28.

Lechthaler, W. and Mileva, M. (2014). Trade Liberalization and Wage Inequality: New Insights from a Dynamic Trade Model with Heterogeneous Firms and Comparative Advantage. Kiel Institute for the World Economy, no. 1886.

Mahutga, M. and Bandelj, N. (2008). Foreign Investment and Income Inequality, The Natural Experiment of Central and Eastern Europe. International Journal of Comparative Sociology, vol. 49 (6), pp.429-454.

Meschi, E. and Vivarelli, M. (2007). Globalization and Income Inequality. IZA Discussion Paper, no. 2958.

Milanovic, B. (1999). Explaining the Increase in Inequality during Transition. Economics of Transition, vol. 7, no. 2, pp.299-341.

Milanovic, B. (2011). More or Less. Income inequality has risen over the past quarter-century instead of falling as expected. Finance and Development. IMF, vol.48. no.3, pp. 6-11.

Mitra, P. and Yemtsov, R. (2006) Increasing Inequality in Transition Economies: Is there more to come? World Bank Policy Research Working Paper no. 4007.

OECD (2002). Foreign Direct Investment for Development. Maximising Benefits, Minimising Costs, Organisation for Economic Co-Operation and development, Paris, France.

Onaran, Ö. and Stockhammer, E. (2008). The effect of FDI and foreign trade on wages in the Central and Eastern European Countries in the post-transition era: A sectoral analysis for the manufacturing industry. Structural Change and Economic Dynamics, no. 19, pp. 66-80.

Peter, K. (2003). Skill-Biased Transition: The Role of Markets, Institutions, and Technological Change. IZA Discussion Paper, no. 893.

Roaf, J., Atoyan, R., Joshi, B., Krogulski, K. and IMF Staff Team (2014). 25 Years of | Transition Post-Communist Europe and the IMF. International Monetary Fund-, Regional Economic Issues Special Report, October. 
Roodman, D. (2006). How to do xtabond2: An Introduction to "Difference" and "System" GMM in Stata, The Center for Global Development- Working Paper, no. 103.

Roodman, D. (2009). A note on the theme of too many instruments. Oxford Bulletin of Economics and Statistics, vol. 71, no. 1, pp.135-158.

Rose, S. (2014). Income Inequality in Post-Communist Central and Eastern European Countries. Eastern Journal of European Studies, vol.5, issue 1, pp. 5-19.

Satti, S., Mahalik, M., Bhattacharya, M. and Shahbaz, M. (2015). Dynamics of Income Inequality, Finance and Trade in Kazakhstan: Empirical Evidence from a New Transition Economy with Policy Prescriptions. Monash Business School, Department of Economics, Discussion Paper, no.36.

Topel, R. (1997). Factor Proportions and Relative Wages: The Supply-Side Determinants of Wage Inequality. The Journal of Economic Perspectives, vol. 11, no. 2, pp. 55-74.

Tyrowicz, J., Velde, L. and Svejnar, J. (2017). Effects of Labour Reallocation on Productivity and Inequality-Insights from Studies on Transition. Journal of Economic Surveys, vol. 31, no.3, pp. 712-732.

UNCTAD (2003). World Investment Report. FDI Policies for Development: National and International Perspectives, United Nations, New York and Geneva.

UNCTAD (2010). World Investment Report. Investing in a Low-Carbon Economy. United Nations, New York andGeneva.

UNCTAD (2012). World Investment Report. Towards a New Generation of Investment Policies, United Nations, New York and Geneva.

WNCTAD (2013). World Investment Report. Global Value Chains: Investment and Trade for Development, United Nations, New York and Geneva.

Zulfiu Alili, M. (2014). Simulation Analysis of the Effects of Increased Foreign Ownership on Wage Inequality. Academicus International Scientific Journal, issue 9, pp. 140-158. 


\section{Appendix 1- Unit root test}

Investigating for spurious regressions we test for unit root or non-stationarity in the panel dataset. Stata xtunitroot command performs several tests for panel data unit roots. The LevinLin-Chu (2002), Harris-Tzavalis (1999), Breitung (2000; Breitung and Das 2005), Im-PesaranShin (2003), and Fisher-type (Choi 2001) tests have the null hypothesis that all the panels contain a unit root. The Hadri (2000) Lagrange multiplier (LM) test has as the null hypothesis that all the panels are stationary (Maddala and $\mathrm{Wu}, 1999)$. However most of the tests require balanced data. The Im-Pesaran-Shin and Fisher-type tests allow for unbalanced data, but the ImPesaran-Shin test cannot have gaps in data. Therefore the only test which can be implemented in this study is the Fisher-type test. The null hypothesis is that all series are non-stationary against the alternative that at least one series in the panel is stationary. The Fisher test is based on combining the $\mathrm{p}$-values of the test-statistic for a unit root in each cross-sectional unit, it is nonparametric which gives the $p$-values $\pi_{1 \mathrm{i}}$ and then $-2 \sum \log _{\mathrm{e}} \pi_{\mathrm{i}} \sim \chi^{2}$ with $2 N$ d.f., where $N$ is the number of separate samples (Maddala and $\mathrm{Wu}, 1999)$. The test statistics for the Fisher-type panel unit root test are reported in the table below. Out of the ten panel variables, the test statistics are significant for seven variables at 5\% level, rejecting the null hypothesis of unit root. In addition to the unit root test all variables are plotted to check for stationarity (results are available upon request). As the graphs show some cross sections for some variables have very short time dimensions and considering the alternative hypothesis that at least one series in the panel is stationary one can not make a strong conclusion that there is a unit root in the panel. In addition, the test statistic for this test is valid when $\mathrm{T}$ approaches to infinity, which implies a long time period, whereas the time period in our estimations is quite short. "For small T, panel unit root tests have low power and there is the potential risk of concluding that the whole panel is nonstationary even when there is a large proportion of stationary series in the panel" (Baltagi, 2005 , p.247). Since the main variables of interest (GINI and FDI) are found to be stationary, while the potential danger of spurious regression in the case of a unit root would be more of a problem if the model had non-stationary variables both on the left and right hand side, we proceeded with the empirical analysis under the assumption that there is no unit root in the panel.

\section{Fisher Test for panel unit root using an augmented Dickey-Fuller test (0 lags)}

\begin{tabular}{|c|c|c|c|c|c|}
\hline $\begin{array}{l}\text { Variable } \\
H_{0} \text { : unit root }\end{array}$ & T-statistic (TS) & Prob. & $<>$ & $\begin{array}{l}\text { CV } \\
(5 \%)\end{array}$ & Decision \\
\hline GINI & $\operatorname{chi} 2(34)=108.79$ & 0.00 & $>$ & 48.60 & $\begin{array}{l}\text { If TS }>\mathrm{CV} \rightarrow \text { Reject } \mathrm{H}_{0} \\
\text { (Stationary) }\end{array}$ \\
\hline THEIL & $\operatorname{chi} 2(30)=83.55$ & 0.00 & $>$ & 43.77 & $\begin{array}{l}\text { If TS }>C V \rightarrow \text { Reject } \mathrm{H}_{0} \\
\text { (Stationary) }\end{array}$ \\
\hline FDI & $\operatorname{chi} 2(32)=362.08$ & 0.00 & $>$ & 46.19 & $\begin{array}{l}\text { If TS }>\mathrm{CV} \rightarrow \text { Reject } \mathrm{H}_{0} \\
\text { (Stationary) }\end{array}$ \\
\hline SQFDI & $\operatorname{chi} 2(32)=115.69$ & 0.00 & $>$ & 46.19 & $\begin{array}{l}\text { If TS }>\mathrm{CV} \rightarrow \text { Reject } \mathrm{H}_{0} \\
\text { (Stationary) }\end{array}$ \\
\hline DOM & $\operatorname{chi} 2(34)=49.29$ & 0.04 & $>$ & 48.60 & $\begin{array}{l}\text { If TS }>\mathrm{CV} \rightarrow \text { Reject } \mathrm{H}_{0} \\
\text { (Stationary) }\end{array}$ \\
\hline TRADE & $\operatorname{chi} 2(34)=115.49$ & 0.00 & $>$ & 48.60 & $\begin{array}{l}\text { If TS }>C V \rightarrow \text { Reject } \mathrm{H}_{0} \\
\text { (Stationary) }\end{array}$ \\
\hline GDP & $\operatorname{chi} 2(30)=17.58$ & 0.96 & $<$ & 43.77 & $\begin{array}{l}\text { If TS }<C V \rightarrow \text { There is insufficient } \\
\text { evidence to reject } \mathrm{H}_{0} \\
\text { (Unit root) }\end{array}$ \\
\hline EDU & $\operatorname{chi} 2(30)=10.20$ & 0.99 & $<$ & 43.77 & $\begin{array}{l}\text { If } \mathrm{TS}<\mathrm{CV} \rightarrow \text { There is insufficient } \\
\text { evidence to reject } \mathrm{H}_{0}\end{array}$ \\
\hline
\end{tabular}




\begin{tabular}{llllll}
\hline LFEDU & chi2 $(18)=4.01$ & 0.99 & $<$ & 28.87 & $\begin{array}{l}\text { (Unit root) } \\
\text { If TS }<\text { CV } \rightarrow \text { There is insufficient } \\
\text { evidence to reject } \mathrm{H}_{0} \\
\text { (Unit root) }\end{array}$ \\
\hline UN & chi2(32)=51.99 & 0.01 & $>\quad 46.19$ & $\begin{array}{l}\text { If TS }>\text { CV } \rightarrow \text { Reject } \mathrm{H}_{0} \\
\text { (Stationary) }\end{array}$ \\
\hline IEF & chi2(30)=196.26 & 0.00 & $>\quad 43.77$ & $\begin{array}{l}\text { If TS }>\text { CV } \rightarrow \text { Reject } \mathrm{H}_{0} \\
\text { (Stationary) }\end{array}$ \\
\hline
\end{tabular}

Note: All variables are in log form.

Plot of the variables to check for stationarity

Plot of GINI1 variable
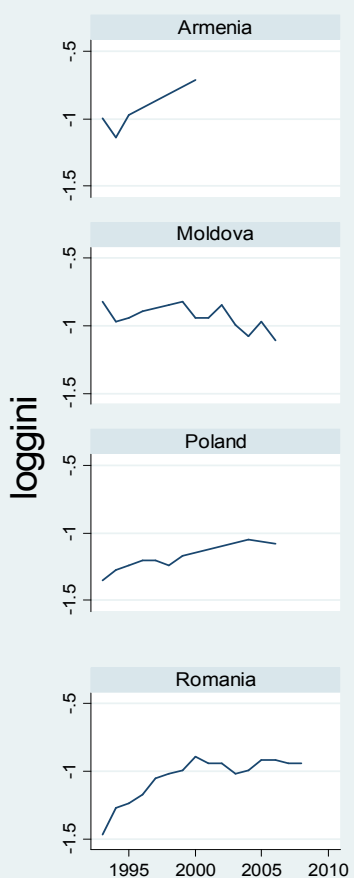

Graphs by index
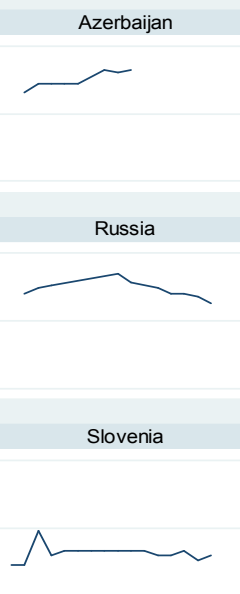

Bulgaria

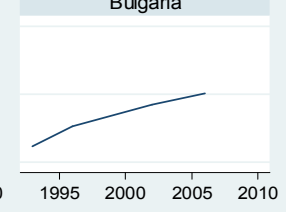

Kazakhstan

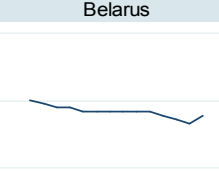

Ukraine

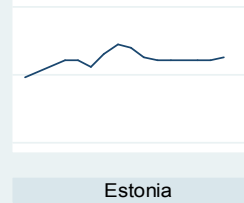

Estonia

Macedonia

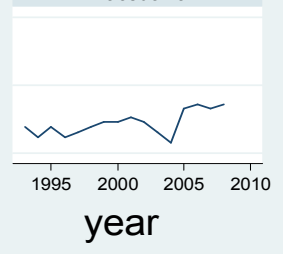

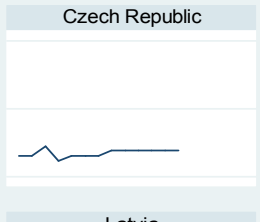

Latvia

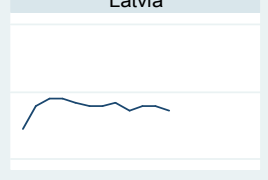

Serbia

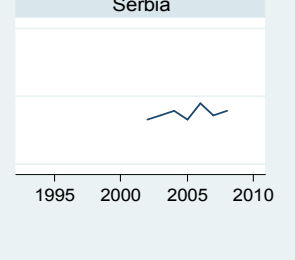

Kyrgyzstan

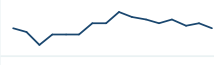

Hungary

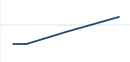

Lithuania

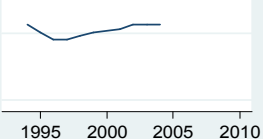


Plot of FDI stock variable
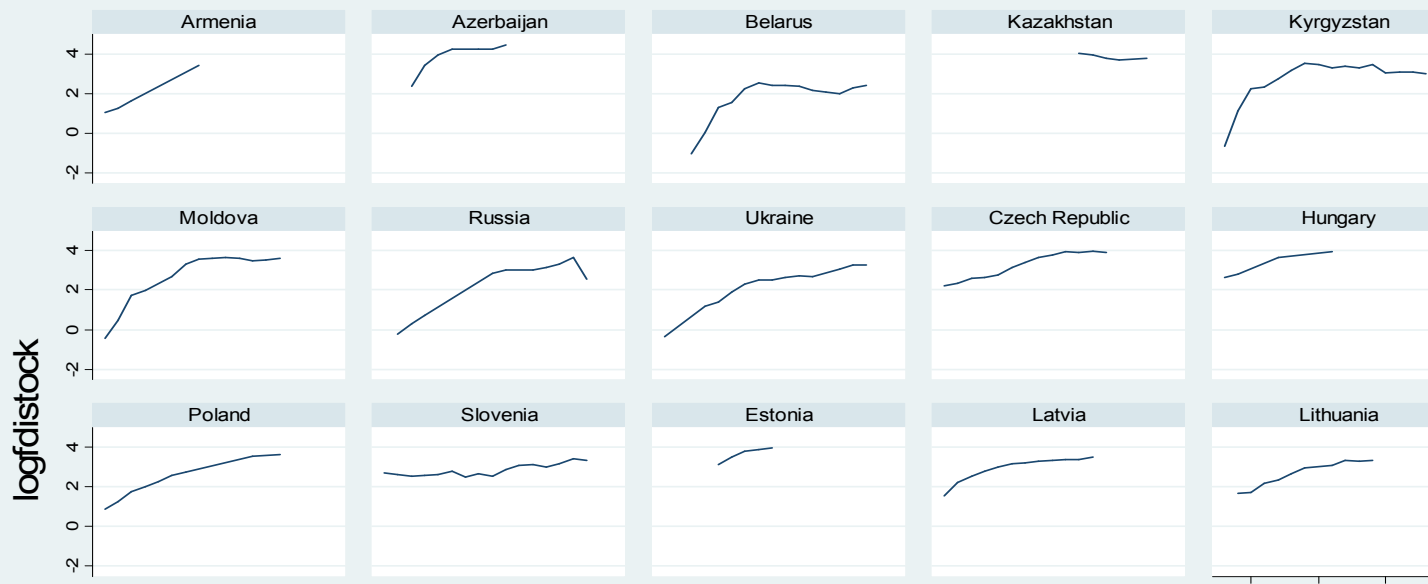

Russia

Ukraine
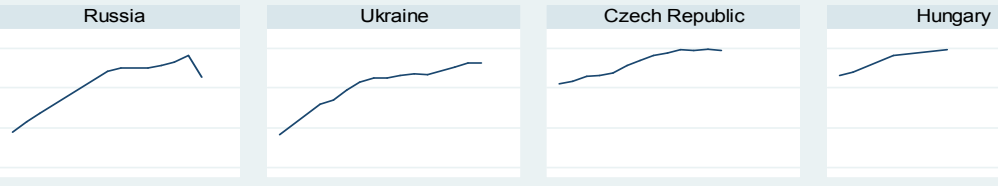

Slovenia

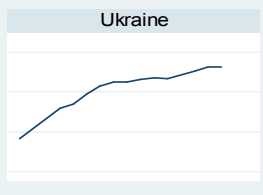

Latvia
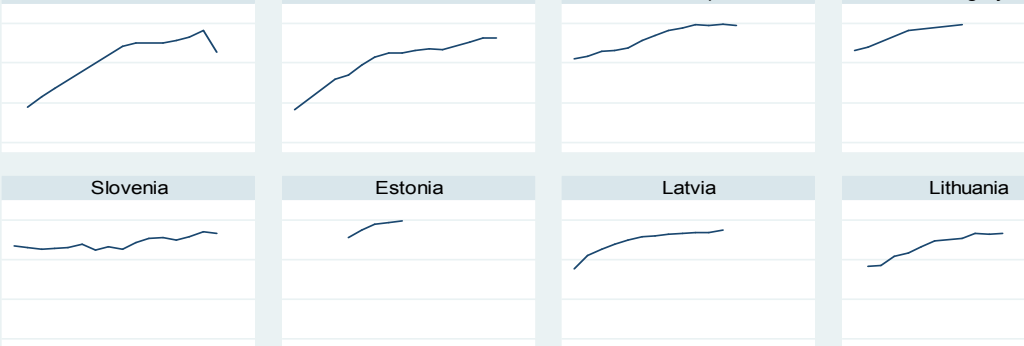

Estonia
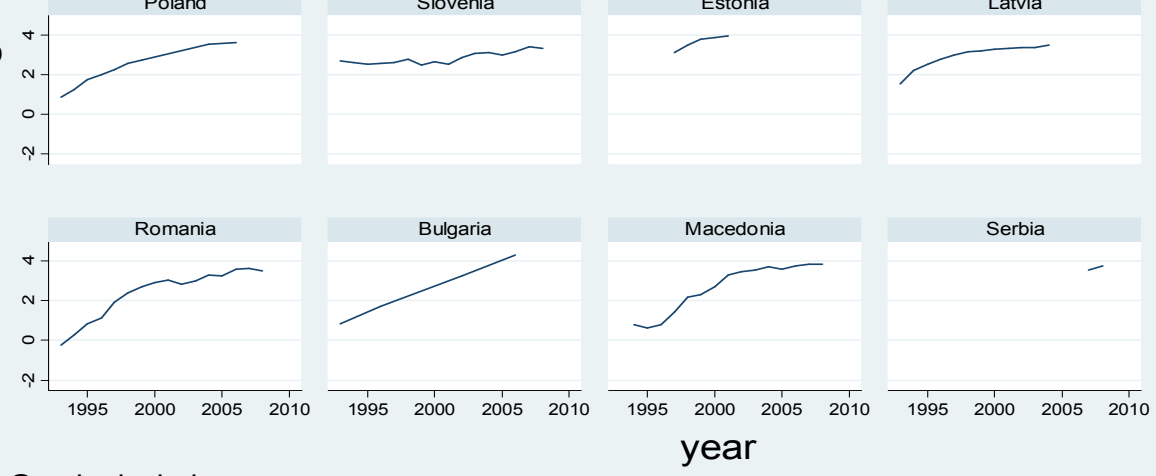

Graphs by index

Plot of Domestic Investment variable
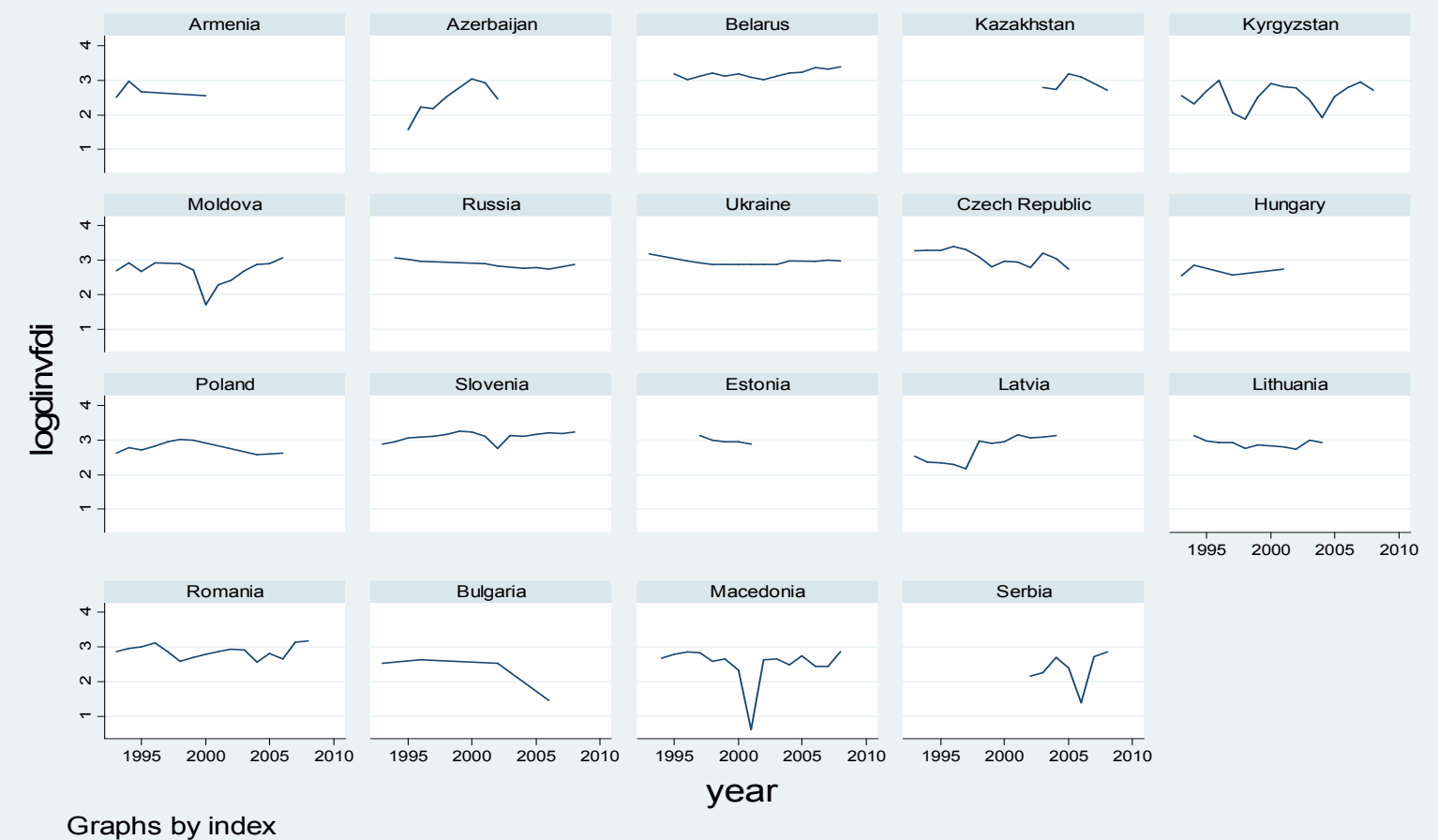


\section{Plot of TRADE variable}

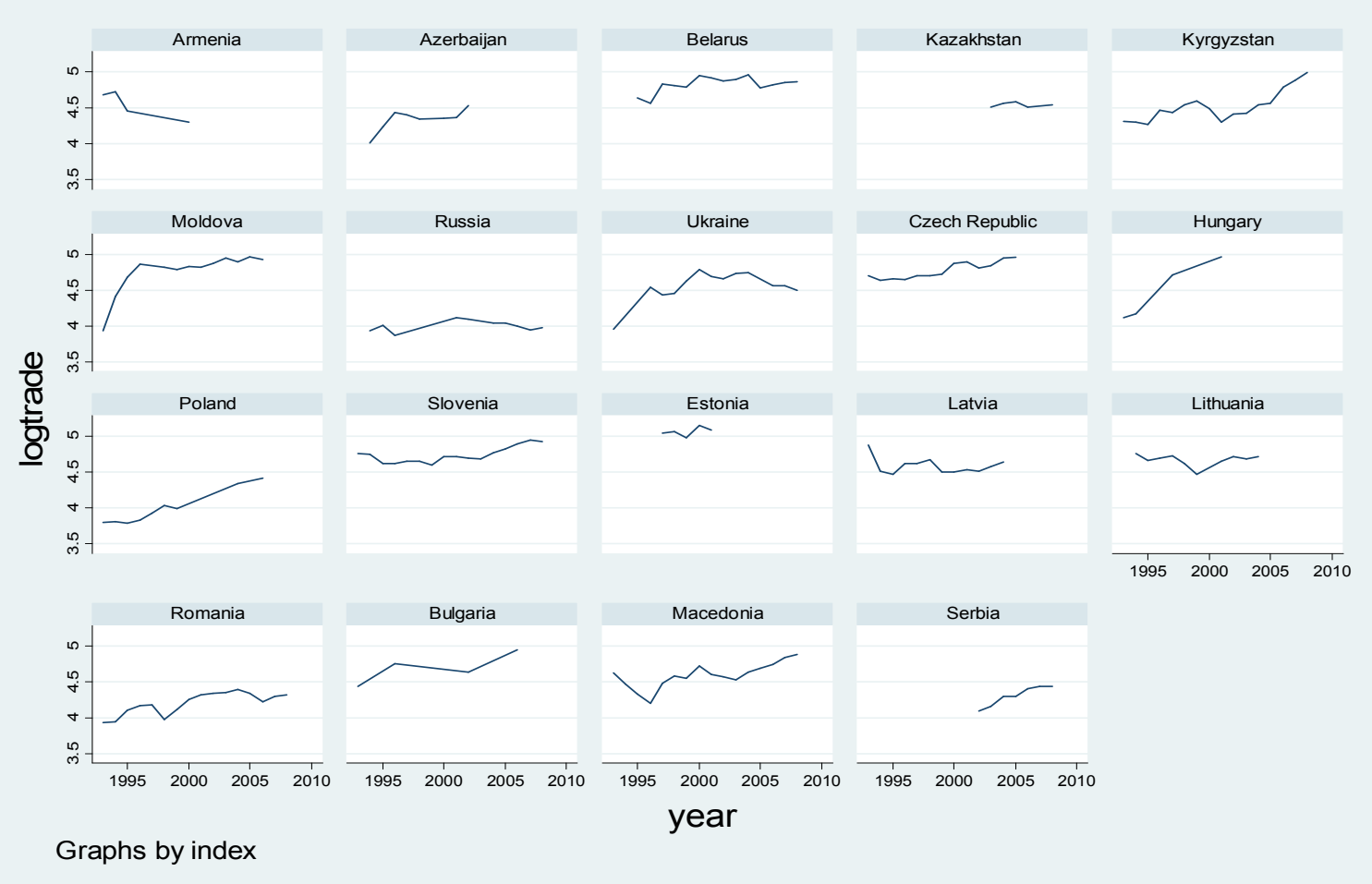

Plot of GDP per capita

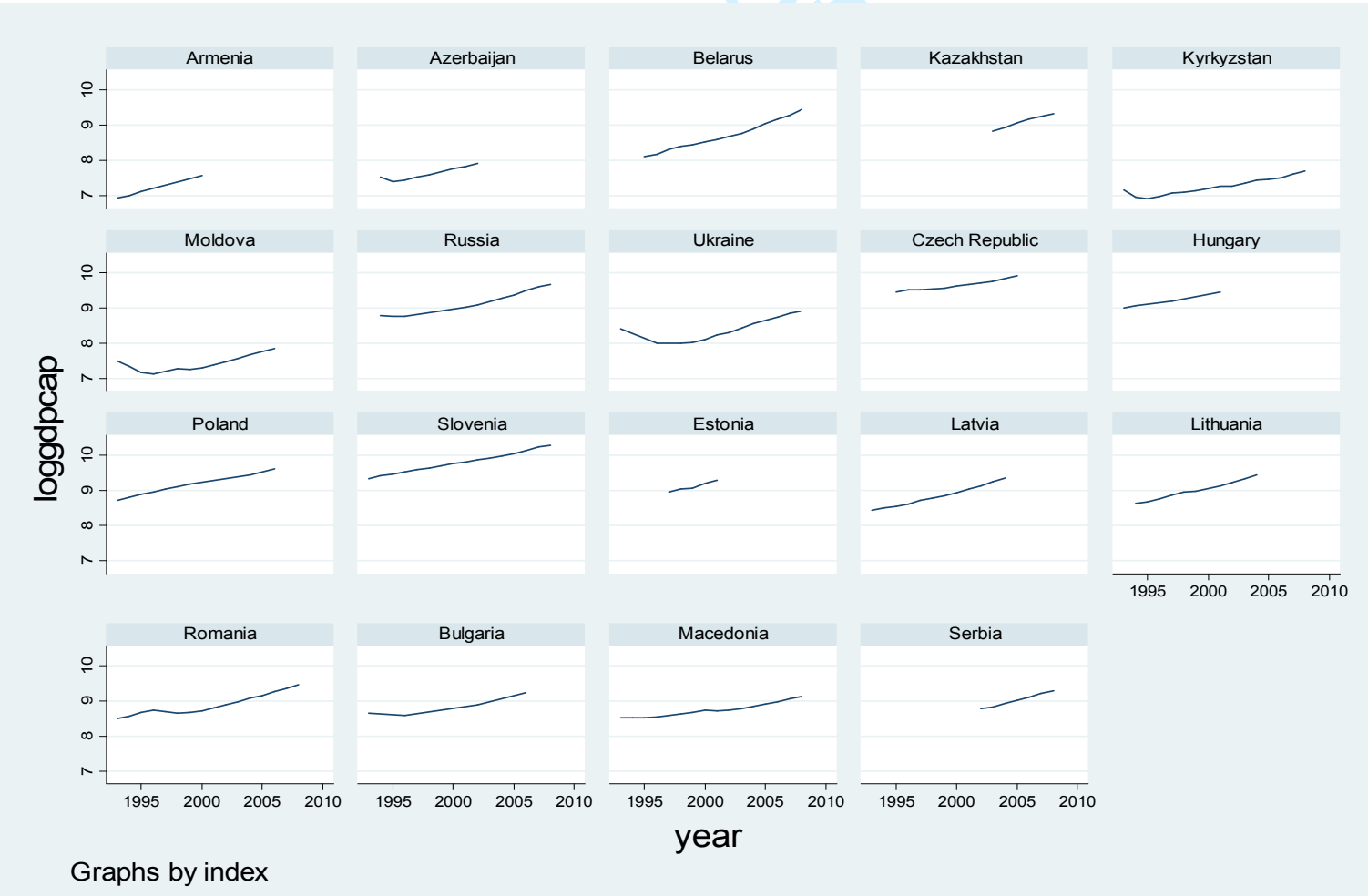


Plot of Tertiary School Enrolment variable
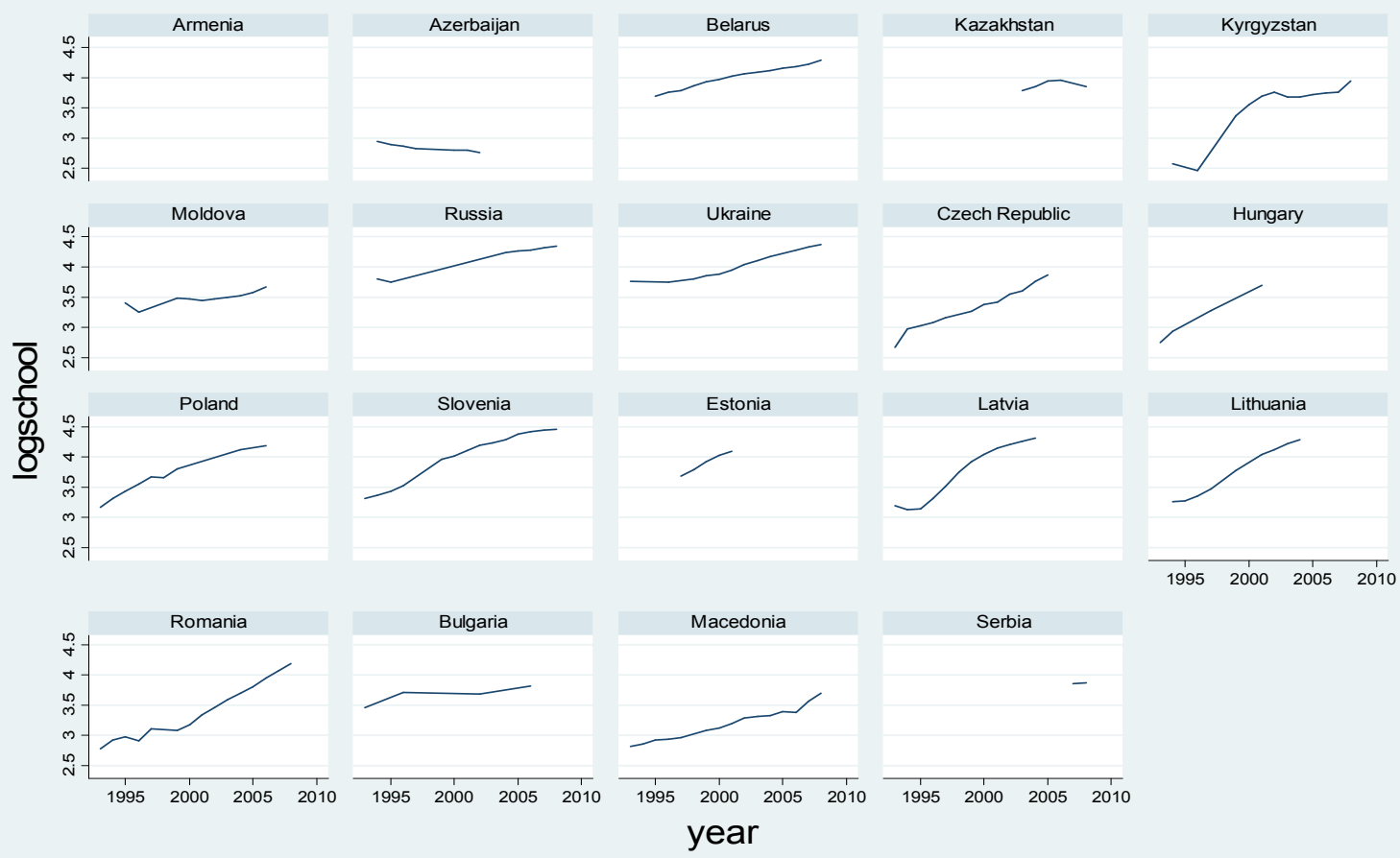

Graphs by index

\section{Plot of Labour Force with Tertiary Education variable}

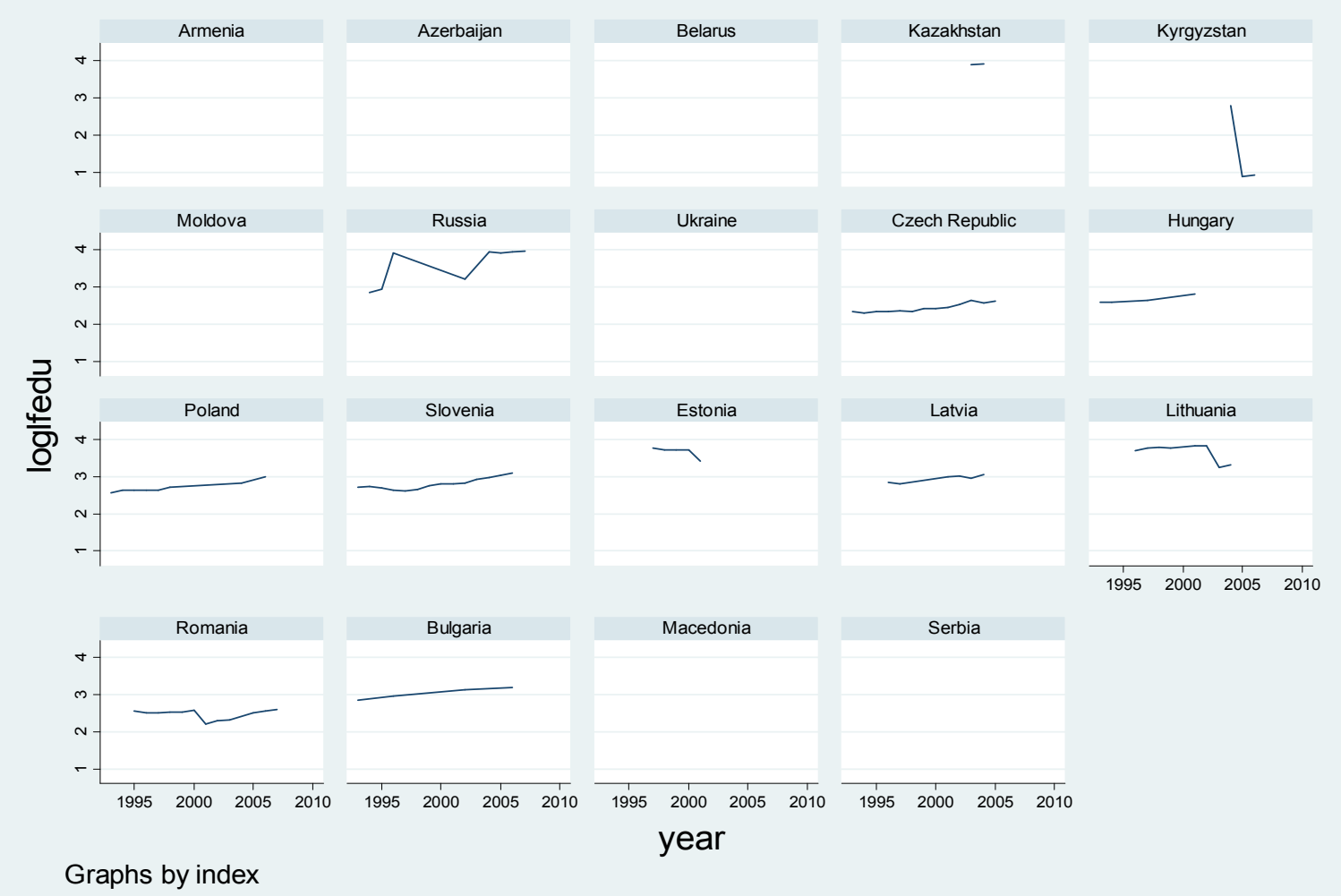




\section{Plot of Unemployment Rate variable}
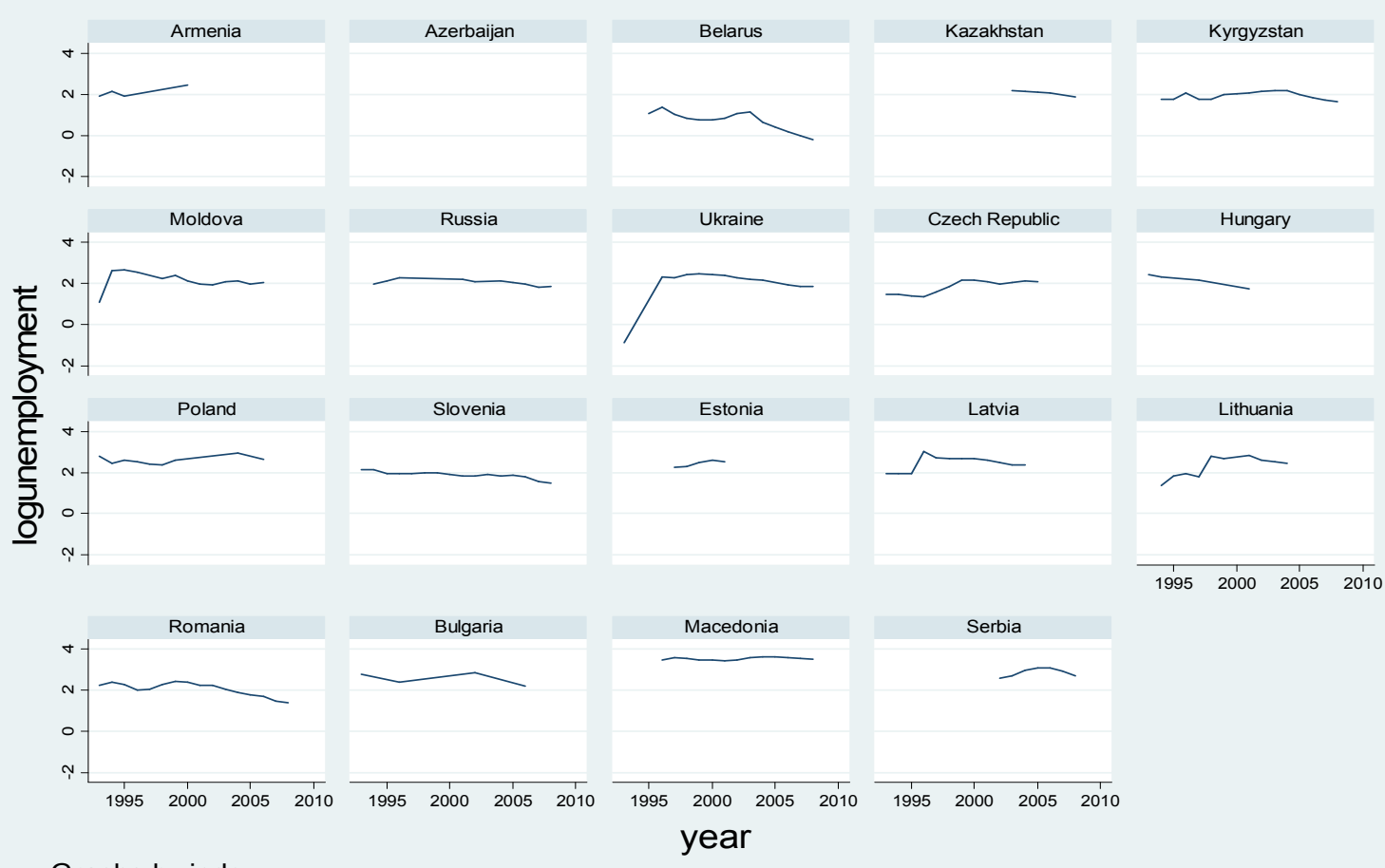

Graphs by index

Plot of Index of Economic Freedom variable

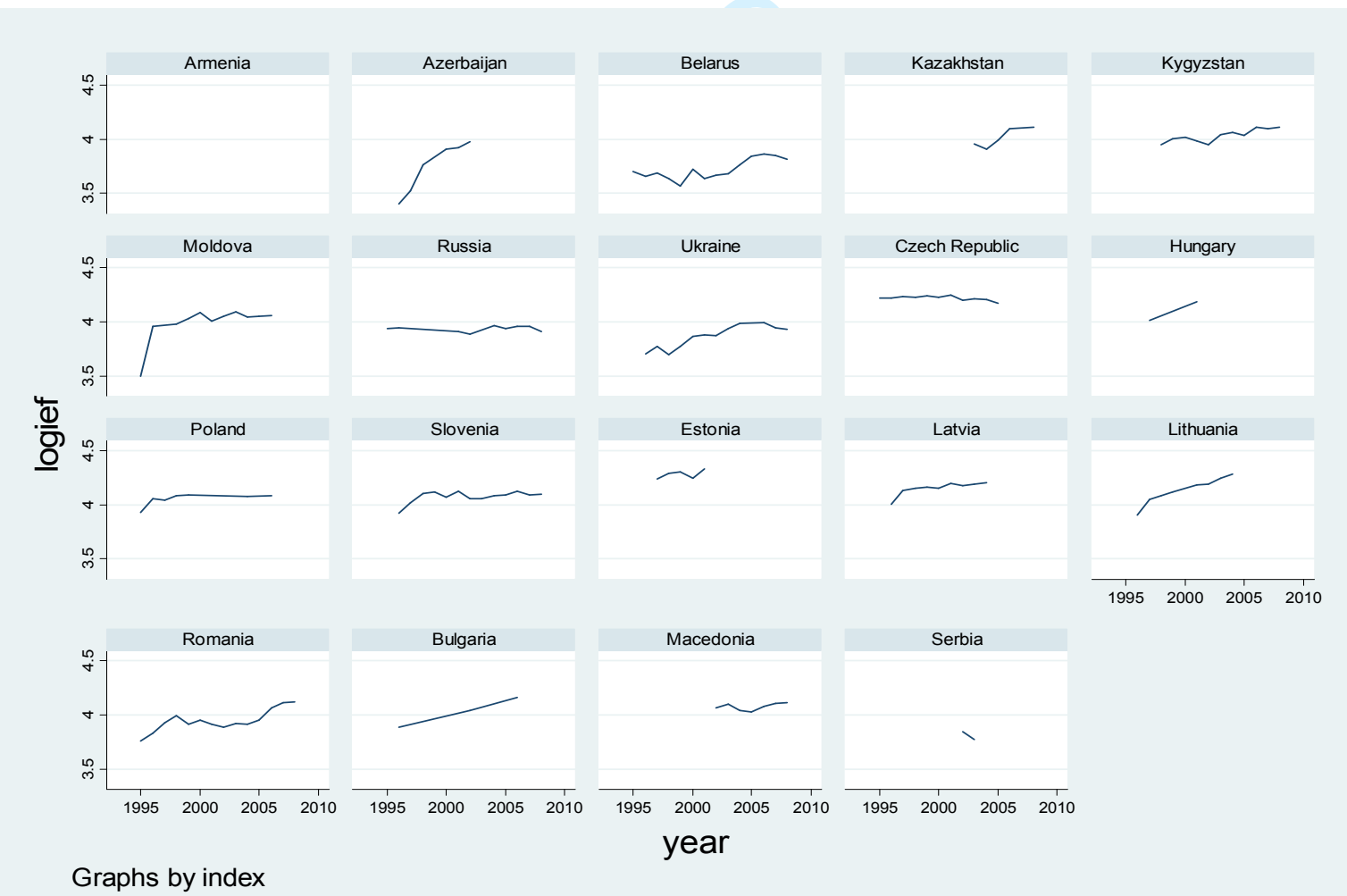




\section{Plot of THEIL variable}
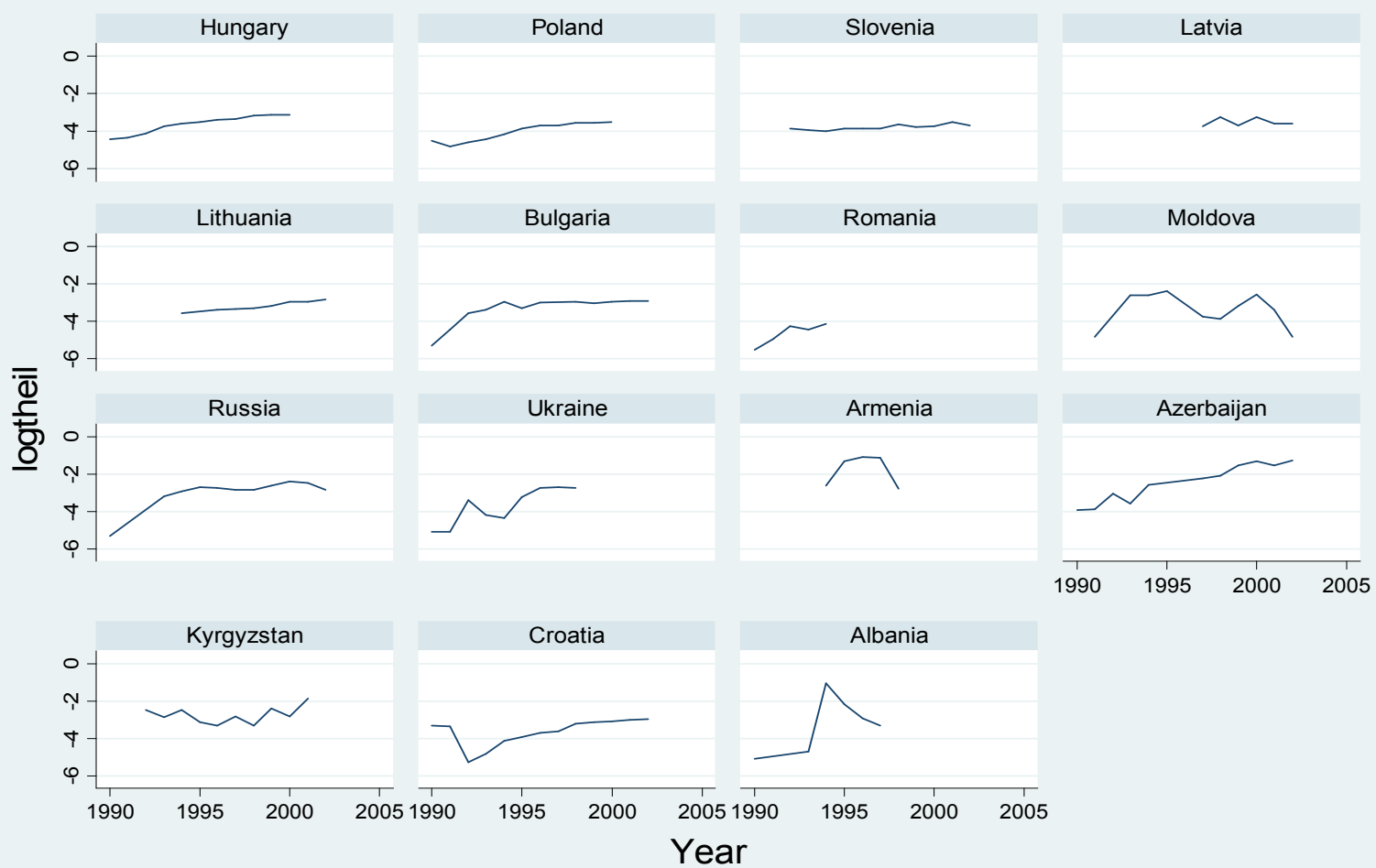

Graphs by Index 